\title{
Economic Inequality in Preindustrial Germany, ca. 1300-1850
}

\author{
Guido Alfani, Victoria Gierok, and Felix Schaff
}

\begin{abstract}
This article provides an overview of wealth inequality in Germany during 1300 1850 , introducing a novel database. We document four alternating phases of inequality decline and growth. The Black Death (1347-1352) led to inequality decline, until about 1450 . Thereafter, inequality rose steadily. The Thirty Years' War (1618-1648) and the 1627-1629 plague triggered a second phase of inequality reduction. This distinguishes Germany from other European areas where inequality grew monotonically. Inequality growth resumed from about 1700, well before the Industrial Revolution. Our findings offer new material to current debates on the determinants of inequality change in western societies, past and present.
\end{abstract}

\section{$\mathrm{R}$} ecent years have seen a flourishing of studies on preindustrial inequality, which has matched a growing interest in long-term distributive dynamics and the factors leading to an increase or decline in inequality. The Great Recession heightened the interest in inequality and made it a hot topic in political debates (Wade 2014; Alfani 2021). Academic interest in inequality has also been fueled by Piketty's explicit attempt to "[place the] study of distribution and of the long-run back at the center of economic thinking" (Piketty 2015, p. 68). A crucial feature of the research projects that belong to this new wave of research

The Journal of Economic History, (C) The Author(s), 2022. Published by Cambridge University Press on behalf of the Economic History Association. This is an Open Access article, distributed under the terms of the Creative Commons Attribution licence (http:// creativecommons.org/licenses/by/4.0/), which permits unrestricted re-use, distribution, and reproduction in any medium, provided the original work is properly cited. doi: 10.1017/ S0022050721000607

Guido Alfani is Professor, Bocconi University - Social and Political Sciences, Milan, MI Italy. E-mail: guido.alfani@unibocconi.it (corresponding author). Felix Schaff is a Ph.D. Candidate, London School of Economics and Political Science, London, UK, United Kingdom of Great Britain and Northern Ireland. E-mail: f.s.schaff@lse.ac.uk. Victoria Gierok is a Ph.D. Candidate, Nuffield College, Oxford University, Oxford, Oxfordshire, United Kingdom of Great Britain and Northern Ireland. E-mail: victoria.gierok@history.ox.ac.uk.

This paper greatly benefited from discussions with, and comments from, Thilo Albers, Ulrich Pfister, Oliver Volckart, and Simone Wegge. We are grateful to Sheilagh Ogilvie for having shared data about inequality in Wildberg, as well as to the editor of this journal, Dan Bogart, and the anonymous referees for their many helpful comments. The research leading to these results has received funding from the European Research Council under the European Union's Seventh Framework Programme (FP7/2007-2013)/ERC Grant agreement No. 283802, EINITE-Economic Inequality across Italy and Europe, 1300-1800, as well as under European Union's Horizon 2020 Framework Program/ERC Grant agreement No. 725687, SMITE-Social Mobility and Inequality across Italy and Europe, 1300-1800. 
on inequality is that they attempt to improve our knowledge of long-run dynamics.

For a long time, the distributive dynamics characterizing the preindustrial period have been the object more of speculation than of proper measurement. This is now changing, and the new evidence that has recently become available is affecting very significantly how we look at long-term trends in economic inequality, particularly in two respects: the causes of inequality change, and the distributive impact of major catastrophes. Regarding the first point, a crucial aspect is that the newly-available studies do not generally confirm the Kuznetsian paradigm (see Alfani 2021 for a synthesis). In 1955, Kuznets argued that inequality, starting from a low level in preindustrial times, increased at the beginning of industrialization, thereafter following an inverted-U path throughout the industrialization process: the so-called "Kuznets curve." But inequality was found to have been on the rise since at least the beginning of the early modern period in almost all areas object of systematic research, so that on the eve of industrialization it was already relatively high. This raises many questions about the causes of inequality change, which can no longer be assumed to consist solely in economic growth: the evidence for preindustrial times suggests that inequality growth also occurred in phases of economic stagnation or decline (Alfani 2010a, 2015; Alfani and Ryckbosch 2016; Alfani and Ammannati 2017; Alfani and Di Tullio 2019). In this sense, studies of preindustrial inequality contribute significantly to current debates on recent trends.

Regarding the distributive impact of major catastrophes, many have argued that the Black Death of 1347-1352 caused significant inequality reduction (Alfani 2015, 2022; Alfani and Ammannati 2017; Milanovic 2016). Scheidel (2017) has extended this argument to include, among the events able to cause substantial leveling, catastrophes leading to largescale material destruction, like major wars, and institutional collapse. And yet, while a strong case has been made about the ability of the world wars to reduce inequality (Piketty 2014), we lack direct evidence about the leveling power of preindustrial wars that tended to be much less destructive. On the contrary, it has recently been argued that in the medium- and long-run war, and more generally the growing investment in the military associated with the rise of the fiscal-military state, led to inequality growth because of the resulting increases in regressive taxation (Alfani and Di Tullio 2019; Schaff 2020; Alfani 2021).

\footnotetext{
${ }^{1}$ Although Kuznets's hypotheses were mainly concerned with income, it stands to reason that they can be also applied to wealth, as more or less explicitly suggested by a growing number of studies (e.g., Lindert 1991; Alfani 2010a, 2021; Milanovic 2016; Scheidel 2017).
} 
Notwithstanding the recent focus, the debate on long-run inequality trends continues to suffer from a lack of research. This is especially serious for central and eastern Europe, which has been covered only marginally (if at all) by recent studies, bar for Poland (Malinowski and Van Zanden 2017). In particular, what is now the largest and most populous state of the European Union, Germany, has been neglected. ${ }^{2}$ We set out to fill this gap by making use of new archival data and of a large amount of published information. We also contribute to the general debate about the long-term determinants of inequality change as well as to the more focused debate on the distributive consequences of catastrophes.

After discussing the pre-existing literature on German inequality, we document four alternating phases of inequality decline and growth during the period from ca. 1350 to 1850 . As we show, Germany-like the rest of Europe - experienced a phase of reduction in wealth inequality triggered by the Black Death. This was followed by a phase of growth in economic disparities until the end of the sixteenth century. Afterward, the case of Germany departs from that of the other European areas that have been researched so far, because the exceptionally devastating Thirty Years' War of 1618-1648 and the concomitant epidemics and famines led to the second phase of inequality decline. As we argue, had Germany not experienced this terrible conflict, it would probably have been much more unequal by the eighteenth or even the nineteenth century. We begin with a case-by-case analysis, followed by a reconstruction of the general wealth inequality trend across Germany. Given the political fragmentation that characterized this area until 1871 , it would have been preferable to proceed first with reconstruction at the level of at least the main German pre-unification states: as done for Italy by the EINITE project. ${ }^{3}$ Unfortunately, the information currently available simply does not allow us to do this - so we propose our overall reconstruction as the first step in a process whose ultimate goal is to integrate Germany adequately into the current debates about inequality.

\section{WHAT WE KNOW ABOUT ECONOMIC INEQUALITY IN PREINDUSTRIAL GERMANY}

This section reviews the distinct streams of literature that have dealt with economic inequality in preindustrial Germany. We begin with the studies of the early German Historical School, which tended to focus on

\footnotetext{
${ }^{2}$ A study of the principality of Hesse-Cassel in the 1850s is the exception (Wegge 2021).

${ }^{3}$ www.dondena.unibocconi.it/EINITE
} 
the micro-level (inequality between households or individuals), then we explore the methodologically similar studies published since the postwar period. Finally, we briefly examine the recent literature that mapped broader trends across Europe. As Germany has been largely absent from this recent literature, we argue for a new approach to the study of inequality in this area, one capable of capturing broad secular trends. This approach must be backed by a large database of local inequality measures sufficiently homogeneous and comparable across time and space.

\section{Economic Inequality in Germany: Lessons from Local Studies- from the German Historical School Until Today}

The German Historical School was among the first to consider economic inequality in preindustrial Germany. Works by Schmoller (1895), Bücher (1917), and Jecht (1926) laid the groundwork. Their empirical, descriptive approach was followed by other scholars, which led to a number of case studies using wealth tax data from the fourteenth to the seventeenth century. ${ }^{4}$ These early studies primarily left an empirical legacy of using (pre-) statistical data to describe the social structure of a community. However, they rarely attempted any kind of comparison beyond the immediate cases studied, and they contain little interpretation or analysis beyond their descriptive findings. Despite this apparent limitation, the works of the German Historical School achieved their intended purpose of providing fuel for the political advocacy of social reforms to curb rising inequality at the turn of the twentieth century. A detailed discussion of this literature is provided in Online Appendix 1.

Most post-war research on economic inequality is characterized by a methodological approach similar to that of the German Historical School. ${ }^{5}$ Again, wealth tax registers of the preindustrial period were used as the main source of information. Usually, analyses of wealth distributions were embedded in detailed studies of the economic and social history of every single community (Kirchgässner 1960; Fügedi 1980; Bátori and Weyrauch 1982). These works have usually been published in German only and most of them have focused on the period from the fourteenth to the sixteenth century, with relative neglect of the seventeenth and eighteenth centuries.

This literature, while ambitious in its own respects, also has limitations. First, because it analyzes social structure by producing synthetic tables

\footnotetext{
${ }^{4}$ See, for example, the works of Hartung (1898), Hartwig (1903), and Dorner (1905).

${ }^{5}$ For the defining methodological paper see Maschke (1973).
} 
of wealth distribution, often expressed in the specific currency of a given community and time, using varying categories and often ad-hoc classifications. The absence of standard categories makes comparisons quite difficult (see, e.g., Hartung 1898, pp. 188-89; Fügedi 1980). Secondly, continuing the methodological tradition of the German Historical School, this literature analyzes inequality in single communities and over short time periods (Jütte 1984, p. 71; Röck 1989; Uthmann 1957, pp. 19-24; Fügedi 1980), which makes it difficult or even impossible to detect longterm trends.

After the 1980s, research on economic inequality in Germany was almost entirely abandoned, but it resurfaced in the new millennium (Warde 2006; von Hippel 2009; Wegge 2021), especially after the Great Recession of 2008, which marked a renewal of interest in the history of distributive dynamics worldwide (see Alfani 2021 for a synthesis). However, most of these new studies focused on specific German areas or communities and did not attempt to reconstruct long-run trends. One notable exception is the recent work by Ulrich Pfister on income inequality (Pfister 2019, 2020; Bracht and Pfister 2020). While Pfister's research contributes substantially to filling a gap in the literature, it focuses on macro-level variables, such as the land rent-wage ratio, from which broad distributive trends can be glimpsed but it does not attempt to measure inequality based on household-level distributions. Thus, we still miss a broader perspective based on a more direct and comparable reconstruction of the actual distribution of income or wealth.

What does the available evidence tell us about the development of economic inequality in preindustrial Germany from the Black Death until the Industrial Revolution? To our best knowledge, there is not a single recent case study that covers the late Middle Ages and the distributive impact of the Black Death (the pandemic affected Germany mostly in 1348-1349). A partial exception is Rodepeter (1998), who has hypothesized that the demographic catastrophe caused by plague reduced income inequality. This, because agricultural and urban workers earned higher wages due to the increased marginal productivity of labor, while landowners suffered from lower rents and from having to pay higher wages. Although this seems plausible, Rodepeter's work remains highly speculative. It is based on assumptions of standard economic theory and fragmentary evidence about prices, wages and rents, partly drawn from other European regions, and not on direct information about the distribution of household income or wealth.

For the early modern period, few studies based on household-level distributions of economic resources have been published so far. Case-study 
evidence points toward a possible increase of inequality and poverty during the sixteenth century (Bátori and Weyrauch 1982, p. 95; Robisheaux 1989, pp. 84-89; Sreenivasan 2004, p. 146; Jütte 1994). Several arguments have been proposed that could explain this pattern, including economic growth, demographic expansion, and inegalitarian resource extraction by specialinterest groups and public authorities (Scheidel 2017, p. 335; Pfister 2019, p. 242, 2020; Ogilvie 1992, pp. 426, 429-34).

The seventeenth century was marked by the Thirty Years' War (16181648) and the "general crisis" that ensued. This conflict, which was the most destructive of early modern Europe, took place mostly in the German territories (Ogilvie 1992). So far, the only evidence about how war affected economic inequality came from one single case study, the city of Augsburg (Roeck 1989). Based on this, it has been hypothesized that the Thirty Years' War was a leveler, leading to a phase of decreasing inequality, which continued until ca. 1700 (Van Zanden 1995; Scheidel 2017, pp. 335-41). The war had many characteristics that theoretically could have had egalitarian implications. However, the literature has mostly focused on the destruction or confiscation of physical assets and the enormous demographic decline - mostly caused by a plague from the 1620s, spread by roving soldiers (Eckart 1996; Outram 2001) - as the drivers of inequality decline (Van Zanden 1995, p. 646; Scheidel 2017, pp. 337-42; Pfister 2020). Interestingly, based on the case of Augsburg, it has been argued that demographic collapse led to inequality decline because the plague disproportionately killed the poor (Scheidel 2017, p. 338). This would fit recent hypotheses about different distributive dynamics following the Black Death and the seventeenth-century plagues. After the Black Death, poverty was reduced because the lower strata experienced an improvement in their relative position, for example, due to increases in real wages. But in the seventeenth century, major plagues in southern and central Europe led to a reduction in poverty mostly because they affected the poor more than any other component of society (Alfani 2022).

Published evidence about German economic inequality during the rest of the early modern period is again quite sparse. Some case studies have suggested that inequality increased between the late eighteenth and the early nineteenth centuries, although with some disagreement about the intensity of the process. Quick population growth and rising poverty linked to early industrialization have been highlighted as the primary drivers (Kocka 1990, pp. 117-20; Sabean 1990, pp. 454-55; Pfister 2020). However, this phase of inequality change seems under-theorized in German literature. New concepts, such as the inequality-increasing role of early-modern state formation (see Alfani 2015, 2019, 2021; Scheidel 
2017; Alfani and Di Tullio 2019) or of rent-seeking and extractive institutions more generally (Acemoglu, Johnson, and Robinson 2005, p. 390; Ogilvie 2021) still have to be applied systematically to the study of preindustrial Germany.

\section{Economic Inequality in Preindustrial Europe: A Brief Overview}

Recent research has added considerably to the amount of information available to explore the dynamics and the underlying causes of inequality change in the very long run. We now have good-quality, datarich reconstructions of long-term trends in (mostly wealth, sometimes income) inequality for many parts of Italy (Alfani 2015, 2017; Alfani and Sardone 2015; Alfani and Ryckbosch 2016; Alfani and Ammannati 2017; Alfani and Di Tullio 2019), Spain (Santiago-Caballero 2011; García-Montero 2015; Alfani 2017), Portugal (Reis 2017), the Low Countries (Van Zanden 1995; Ryckbosch 2016; Alfani and Ryckbosch 2016; Alfani 2017), and Sweden (Bengtsson et al. 2018). Some of these reconstructions cover many centuries. Other recent research focused on single years when exceptional sources were available, for example, in Spain in 1759 (Nicolini and Ramos Palencia 2016, 2021) or Poland in 1578 (Malinowski and Van Zanden 2017). This broad research campaign reached beyond Europe, as preindustrial inequality was explored also for Anatolia under the Ottoman Empire (Canbakal, Filiztekin, and Kokdas 2018), for the pre-revolutionary United States (Lindert and Williamson 2016), for Japan in the late Tokugawa period (Saito 2015), and for Jamaica (Burnard, Panza, and Williamson 2019).

Overall, these studies suggest that after a phase of inequality decline (of both income and wealth) triggered by the Black Death, from ca. 1450 inequality tended to grow across Europe (Portugal is a possible exception to this pattern: Reis 2017). Importantly, this tendency toward inequality growth occurred both in areas and periods characterized by economic growth and in those characterized by stagnation or even decline. This finding prevents us from explaining preindustrial inequality growth as simply the by-product of economic development. Population change is another factor that has been explored as a possible determinant of inequality trends. However, population change did not generally prove any better than economic growth at explaining broad tendencies. More recently, researchers have focused on processes of state formation and of increase in regressive taxation associated with the rise of the fiscalmilitary state (Alfani and Di Tullio 2019; Alfani 2021). We will return to these interpretations in a later section. 
Germany has hitherto been neglected by the new wave of research on preindustrial inequality. ${ }^{6}$ A notable recent exception is the study of the principality of Hesse-Cassel in the 1850s by Wegge (2021), based on a large sample of more than 1,000 towns and villages. This study, however, did not push into earlier epochs. Filling this gap is our first objective. To achieve it, we provide empirical inequality estimates based on fiscal sources, in line with the earlier German scholarship on inequality but with the longrun perspective, which is typical of recent research on other European areas. What we aim to provide is a quantitative, data-driven reconstruction of broad inequality trends based on a large sample of household-level distributions of wealth. Our second objective is to establish the major turning points in inequality trends, with a focus on the distributive consequences of the Black Death and the Thirty Years' War. Our third objective is to compare inequality trends in Germany with the rest of Europe.

\section{SOURCES, DATA, AND METHODS}

This section presents the sources, data, and methods that we use to generate the inequality estimates reported in later sections. ${ }^{7}$ Our dataset comprises 29 cities and 76 rural communities. ${ }^{8}$ To our knowledge, this is by far the most extensive dataset for the study of economic inequality in the German area, both in terms of geographical coverage and of the length of the period considered (compare with Fügedi 1980; Robisheaux 1989; Warde 2006). All communities in our sample lie within the boundaries of present-day Germany, as seen in Figure 1, and almost all belong to the core area of the Holy Roman Empire. Communities were classified as urban if they held official city status (Stadtrecht) and their population exceeded 3,000 inhabitants at any point in the study. Moreover, any community with Imperial City status was classified as a city-regardless of population size - since Imperial Cities were self-governed city-states. This definition fits well with the classifications given by urban historians (Ammann 1978; Stoob 1985; Isenmann 2014). See Online Appendix 3 for a detailed discussion of our classification scheme and population estimates.

\footnotetext{
${ }^{6}$ Some earlier studies covered the nineteenth and twentieth centuries, including Kuznets' seminal article (1955) whose results for the German area have recently been refined but largely confirmed by Bartels (2019) and Albers, Bartels, and Schularick (2020).

${ }^{7}$ Data and other replication files for this article are provided in Alfani, Gierok, and Schaff (2021).

${ }^{8}$ Note that the 76 rural communities comprise a total of 147 individual villages. We do not calculate the Gini index for every single village in our sample but we calculate it at the appropriate administrative level, in other words, the parish or district level- of those there are 76. This, because some villages consisted of very few households. Online Appendix 2 lists all Gini indexes calculated and specifies the respective administrative level.
} 


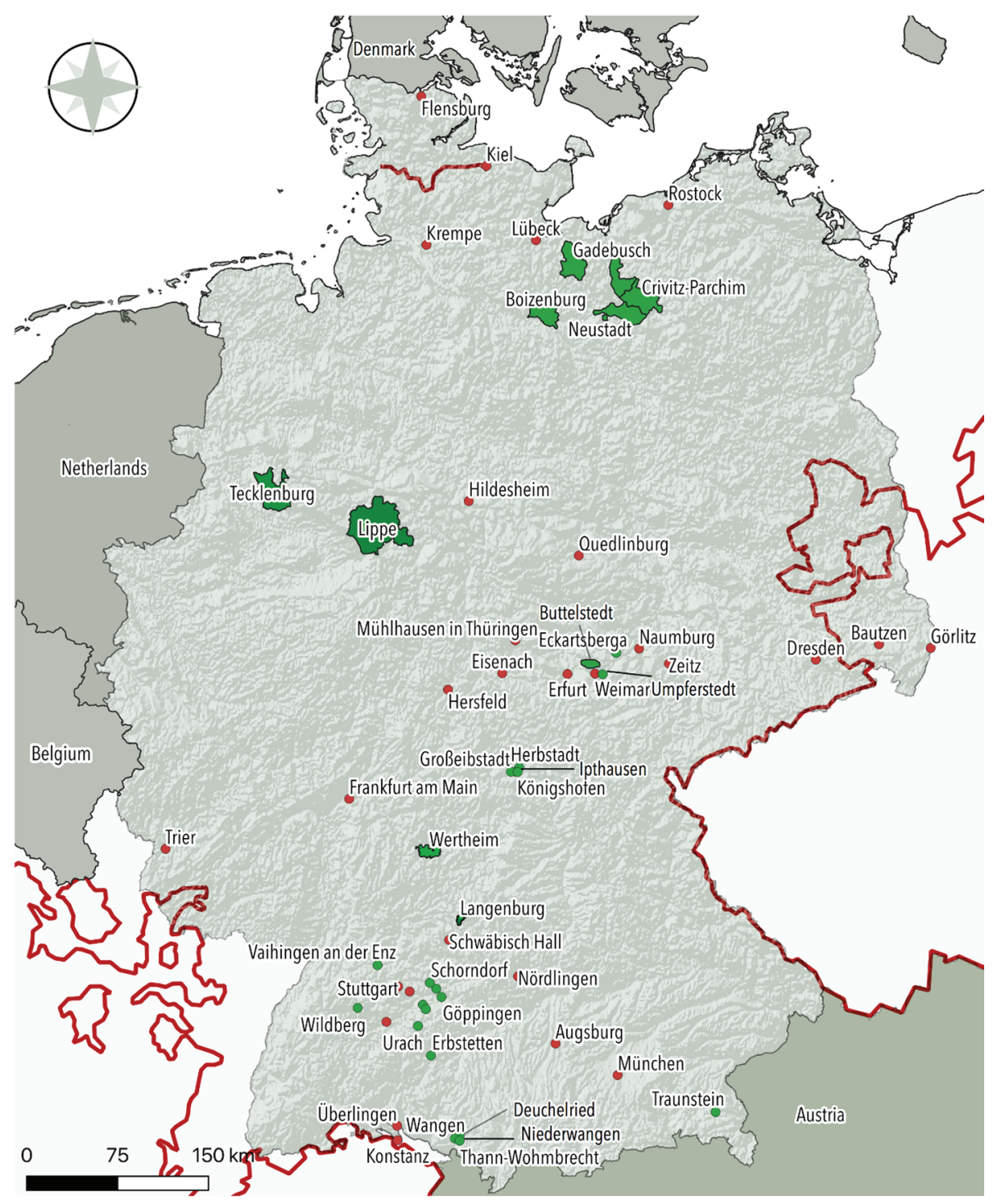

Germany current borders

- Holy Roman Empire 1545 borders

Localities

- Urban

- Rural

FIGURE 1

\section{COMMUNITIES COMPRISED IN THE DATABASE}

Sources: Authors' own elaboration. Borders of the Holy Roman Empire around 1545 from Volckart (2020). 


\section{Sources and Data}

The information we use comes from property tax registers. Exploiting these sources to study wealth inequality is a consolidated tradition in German scholarship (Fügedi 1980; Jütte 1984; Kocka 1990). Although, as discussed later, property tax registers also have some limitations, there is a consensus that they are the best sources available to study socioeconomic structures in preindustrial Germany. Moreover, they are analogous to the sources used to study inequality elsewhere in Europe and thus enable us to compare results (see Alfani and Di Tullio 2019; Alfani 2021 for a synthesis).

A significant part of the data is taken from works of the German Historical School. These authors provided wealth distributions in the form of tables including different wealth brackets and the number of taxpayers within each bracket. Although the information on withinbracket distribution is lost, these tables are sufficiently detailed to allow for the calculation of meaningful inequality measures like the Gini index. This is confirmed by a robustness check comparing Gini indexes built from full distributions with those built from data organized in tax brackets (reported in Online Appendix 4).

Other data come from published primary sources. These are word-forword transcriptions of tax registers kept in archives. They offer a more detailed picture of the wealth distribution, listing all heads of households with either the sum paid or the wealth owned. Additionally, we conducted new archival research on 13 localities: Konstanz, Lübeck, Traunstein, Überlingen, Wildberg, as well as Königshofen, Wangen, and six villages surrounding them (three each). ${ }^{9}$

A challenge when dealing with medieval and early modern tax data is Germany's political fragmentation. In its most fragmented state in the early modern period, the Holy Roman Empire consisted of more than 300 separate sovereign territories (Ogilvie 1996a, p. 121), leading to a variety of tax systems. These systems can be classified based on the Empire's three-tier structure: Imperial taxes paid to the Emperor, territorial taxes collected by the territorial lords, ${ }^{10}$ and city taxes collected by the city councils of - mostly but not exclusively-Imperial and Free Cities. All these taxes were not part of an integrated fiscal system that encompassed the entire Empire. Instead, each political unit constituted a complete fiscal system in itself. City taxes developed first, starting around the

\footnotetext{
${ }^{9}$ See Online Appendix 8 for a complete list of all source material.

${ }^{10}$ The power to tax in the different princely territories of the Holy Roman Empire was often divided between the princes, manorial lords, and knights (Isenmann 1999).
} 
twelfth century. They were general wealth taxes collected once or twice a year and often called Schoß, Geschoss, or Gewerf (Isenmann 1999, p. $243 \mathrm{ff}$.). Territorial and imperial taxes developed later and were often similar in design to city taxes. Despite their wider geographic application, they were still collected at the local level by local authorities and then transferred to higher authorities. A widely-applied imperial tax was the so-called Türkensteuer, an extraordinary tax used in the fifteenth and sixteenth centuries for financing military activities against the Ottomans in the eastern territories of the Holy Roman Empire (von Hippel 2009, p. 6ff.). Online Appendix 3 shows the type of tax used in our analysis for each community in the sample.

A crucial question is who had to pay wealth taxes. The answer differs slightly from city to city. Everywhere, those having the formal status of citizens were the main taxpayers, but the duty to pay taxes was often extended to city dwellers without citizenship and sometimes to servants, usually conditional on surpassing a specific wealth threshold (Table 1 and Isenmann 1999, p. 244). Additionally, all communities granted tax exemptions to certain social categories. These usually included the clergy and sometimes other categories, such as the nobility (see Online Appendix 5 for details).

Fiscal exemptions granted to specific categories do not seriously trouble our reconstructions, because overall they were quite limited. Moreover, tax modalities remained fairly constant over time, which means the observed trends were not influenced by changes in regulations (Hartung 1898, pp. 175-76; Kirchgässner 1964, pp. 80-81, 1967, pp. 78-80; Ohler 1978, pp. 5-7, 26). Instead, our main concern is the propertyless, that is, households that did not own any taxable wealth or were below a minimum threshold for taxation. As they did not have to pay property taxes, they were sometimes omitted entirely from the fiscal records. The exact definition of what constituted being propertyless varied from city to city and does not necessarily mean that these households owned absolutely nothing. In fact, most of the propertyless lived in low-grade dwellings and possessed certain goods necessary for survival. ${ }^{11}$ More importantly, the propertyless were usually few in number, as even tiny morsels of land (like a small orchard) were taxed. ${ }^{12}$

\footnotetext{
${ }^{11}$ The tax registers of Lübeck, for example, often list a number of "huts" with the respective number of "tenants" without specifying their names or tax payments as was systematically done for the wealth tax-paying residents.

${ }^{12}$ It should also be emphasized that our level of analysis is the household and not the individual. This means that servants and poor laborers who lived in their masters' households and who could be propertyless on an individual level could not be observed.
} 
TABLE 1

RESIDENTS' TAX OBLIGATIONS BY CITY

\begin{tabular}{lcccc}
\hline \hline City & Year & Citizens & City-Dwellers* & Servants \\
\hline Augsburg & $1498-1717$ & $\mathrm{x}$ & Lump sum & Per capita tax \\
Bautzen & $1400-1436$ & $\mathrm{x}$ & $\mathrm{x}$ & If above wealth threshold \\
Esslingen & $1403-1458$ & $\mathrm{x}$ & $\mathrm{x}$ & $\mathrm{x}$ \\
Frankfurt a.M. & 1475 & $\mathrm{x}$ & Only immobile wealth & $\mathrm{x}$ \\
Görlitz & 1443 & $\mathrm{x}$ & - & - \\
Hildesheim & $1404-1572$ & $\mathrm{x}$ & $\mathrm{x}$ & If above wealth threshold \\
Kiel & $1448-1488$ & $\mathrm{x}$ & Not taxed & Not taxed \\
Konstanz & $1418-1460$ & $\mathrm{x}$ & $\mathrm{x}$ & If above wealth threshold \\
Lübeck & & $\mathrm{x}$ & - & - \\
Mühlhausen i.Th. & $1418-1553$ & $\mathrm{x}$ & Partly & Not taxed \\
Nördlingen & $1415-1504$ & $\mathrm{x}$ & $\mathrm{x}$ & Partly \\
Quedlinburg & $1310-1585$ & $\mathrm{x}$ & Not taxed & Not taxed \\
Rostock & $1404-1424$ & $\mathrm{x}$ & - & $\mathrm{x}$ \\
Schwäbisch Hall & $1460-1545$ & $\mathrm{x}$ & $\mathrm{x}$ & - \\
\hline
\end{tabular}

Notes: A hyphen indicates that the information is not available. ${ }^{*}$ City-dwellers include non-citizens and guests.

Sources: See Online Appendix 5.

Given that we lack information about the number of propertyless households in certain localities, we remove them from all our distributions. This is a common procedure in studies of preindustrial inequality (Alfani 2015; Alfani and Ammannati 2017), meant to ensure the comparability of our measures of inequality (e.g., Gini indexes) across the sample. As the propertyless were few, even when omitting them the vast majority of the poor remain included in our analyses. This being said, removing the propertyless from the distributions biases our results toward greater equality. To remedy this shortcoming we make use of the information about the propertyless, which is available for 20 out of 29 cities and 69 out of 76 rural communities, to estimate their overall prevalence across time following the procedure detailed in Online Appendix 6. We use these estimates to produce tentative reconstructions that also include the propertyless.

Another shortcoming of property tax records is that - as all fiscal sources in any country or epoch - they do not record all components of wealth, but only those that were subject to taxation. These varied slightly from community to community, but real estate and arable land, which in preindustrial societies constituted by far the main component of wealth, were always taxed. Overall, we found substantial overlap in the definition of taxable wealth across our sample (Online Appendix 5, Figure A5.1 and Table A5.2). This is not surprising, given that many communities 
shared their tax codes with each other to improve their fiscal systems leading to legal convergence (Isenmann 2014, p. 524). Nevertheless, the high degree of fragmentation of the German tax regimes makes the data presented here less coherent compared to other European regions for which long-term trends in wealth inequality have been reconstructed. However, by excluding the propertyless and using only property taxes we ensure a reasonable degree of uniformity in the data.

Similarly, one might wonder whether tax records were structurally different between city and country and consequently, whether our urban and rural data are comparable. We argue that they are comparable, for two reasons. First, several rural villages were taxed by nearby cities (e.g., Mühlhausen, Wangen, and Königshofen) and we have no reason to believe that the taxation procedures were substantially different between city and country as often the urban and rural payments were recorded in the same registers, following exactly the same recording methods. This is also confirmed by a range of in-depth studies of specific cases, like Erfurt (Schrader 1921, pp. 108-109). Secondly, the potential impact on our inequality estimates of small variations in taxation procedures is likely to be negligible. This is suggested by the fact that rural communities and cities follow the same trend and is confirmed by a regression-based robustness check. ${ }^{13}$

\section{Methods}

In analyzing our data we follow the same approach as the recent literature on preindustrial inequality. First, we reconstruct household-level distributions for each community based on the archival sources previously described. The choice of the household level has been made by virtually all recent studies directly comparable to ours (e.g., Alfani 2015; Alfani and Ryckbosch 2016; Reis 2017; Bengtsson et al. 2018).

Secondly, based on the observed distributions, we calculate Gini indexes for each community and year in our sample. This allows for a comparative analysis of local trends in inequality, which is performed in the next section. ${ }^{14}$ The community-level analysis also provides a good benchmark to judge the validity of the aggregate reconstruction.

${ }^{13}$ The regression-based robustness check with locality fixed effects, discussed later, shows that the overall trends we find are not driven by differences in time-invariant community-specific characteristics, tax systems included. This is an important result because the detailed information that would be necessary to adjust for potential differences across communities in terms of the tax base, tax-paying categories or other is currently unavailable. In fact, the statistical test suggests that it is reasonable to assume that our data are sufficiently homogeneous for our analysis.

${ }^{14}$ To ease comparison, we cluster the Gini measures around 50-year breakpoints. 
Thirdly, we produce an aggregate estimate of wealth inequality for Germany as a whole - defined as the area within the current boundaries of the Federal Republic of Germany-from 1350 to 1850. Ideally, one would like to know the actual distribution of wealth, based on information from every household in Germany expressed in one uniform currency. Unfortunately, such census-like information is not generally available for preindustrial societies. A practical solution to this problem is to model the aggregate distribution from sampled local distributions. In essence, we estimate the wealth share of each decile of the population for each locality. These wealth shares are then used to model the aggregate distribution representing all localities. In doing so, we weight the local distributions according to some principal population statistics so that the sample reflects the overall structural characteristics of the population. The goal of the aggregation is thus to approximate the actual distribution of wealth as best as possible. To do this, we follow the method introduced by Alfani (2015) and subsequently applied to a range of preindustrial states. The method is synthetically described later, and Online Appendix 6 provides a detailed explanation.

As a first step, for every sample community in a given year, we model a corresponding distribution consisting of exactly 100 elements or "fictitious households." Each fictitious household receives an empiricallyestimated wealth value, based on the wealth shares calculated from the original distribution reconstructed from archival sources. We take the wealth shares of the population deciles because it is not possible to directly compare the actual taxable wealth of different communities. This, because different sources used different currencies that cannot be reliably converted into a common one. The tenth decile, the richest one, is modeled in greater detail, using information about the top 5 and top 1 percent of the wealth distribution.

In the second step, the fictitious distributions for each city and year are merged into an overall "urban" distribution. Similarly, the distributions for every single rural community and year are merged into an overall "rural" distribution. In order to combine the aggregate urban and rural distribution in an overall "regional" distribution representative of the whole of Germany (third step), two additional weighing issues remain to be solved. First, to take into account that rural households were, on average, less wealthy compared to urban households, we adjust their values taking into account the estimated rural-urban wealth ratio. Secondly, since only a small share of the German preindustrial population lived in cities, we weigh rural and urban distributions by the urbanization rate $(5,000$ inhabitant-threshold). This final weighing is meant 
to achieve, in the aggregate distributions, a ratio between the number of urban and rural elements that matches the urbanization rate. This procedure is analogous to that discussed by Milanovic (2005) to calculate "weighted international inequality." After completing this step, our aggregate distributions representing the whole of Germany are finally ready to use, enabling us to calculate Gini coefficients from 1350 to 1850 .

Finally, we provide a robustness check for our aggregate estimates. Outlined in more detail later, we adopt a regression-based method for aggregating our heterogenous database (see Clark 2005), which yields very similar results compared to our preferred method.

\section{INEQUALITY IN PREINDUSTRIAL GERMANY: EVIDENCE FROM CASE STUDIES}

This section uses a case-by-case approach to first establish four clearly-recognizable phases of alternatively decline and growth in wealth inequality from ca. 1350 to 1850 .

\section{Phase I: The Aftermath of the Black Death}

The first phase which we can detect spans from ca. 1350 to 1450 and is characterized by inequality decline, which we will argue was triggered by the Black Death. Figure 2 plots the developments for a range of cities. The series for several German cities, like Esslingen, Frankfurt, München, and Quedlinburg all show substantial reductions in wealth inequality from 1350 onwards. This declining trend continued well into the fifteenth century. Quedlinburg is a particularly revealing case since it is the only city for which pre-Black Death data are available. Unfortunately, the absence of intermediate observations between 1300 and 1500 leads to some uncertainty about the timing of the reversal of the trend, which might have begun before 1500 .

The case of Rostock is partially different. Starting from a low point of 0.426 in 1378 the Gini index of wealth inequality increased constantly at every following observation, reaching 0.64 around $1550 .{ }^{15}$ This dynamic does not rule out the possibility that pre-Black Death inequality was higher than in the immediately post-crisis years. Indeed, inequality decline in the two-three decades immediately following the Black Death, and early

\footnotetext{
${ }^{15}$ Our first reported estimate in Figure 2 refers to the year 1409 as we only report observations around the 50-year breakpoints, however, the earliest estimate available for Rostock dates from 1378 .
} 
recovery thereafter has been reported for cities in Tuscany (Alfani and Ammannati 2017). The case of Rostock might be explained by its demographic and economic flourishing as part of the German Hansa (Dollinger 1999, pp. 46-47), which experienced a boom in its trading activities after the pandemic (Findlay and O'Rourke 2007, pp. 119-124). This led to a mass migration of poor rural dwellers into Hansa cities, which might have driven up inequality. ${ }^{16}$

The earliest continuous data available for rural areas cover the beginning of the fifteenth century (Figure 3). Therefore, they do not allow for an analysis of the immediate post-Black Death period. Nevertheless, from 1400 onwards, the rural districts of Neustadt and Boizenburg in Mecklenburg show declining inequality. Data prior to 1400 are only available for a number of villages in the County of Wertheim and the bailiwick of Buttelstedt. These data are limited to single years only and have to be interpreted cautiously, however they seem to confirm a decline in the immediate post-Black Death period as the Gini values reported for 1350 are substantially higher than those in 1400 .

\section{Phase 2: From the End of the Middle Ages to the Eve of the Thirty Years' War}

The second phase, from ca. 1450 to 1618 , is characterized by rising wealth inequality. The rise was particularly drastic in the cities of Augsburg, Nördlingen, and Wangen (Figure 2, Phase 2). In Augsburg, wealth inequality increased from 0.449 in 1498 to 0.843 in 1604 . Inequality growth was less pronounced in Schwäbisch Hall, Konstanz, and Überlingen. Two exceptions to this upward trend exist: Frankfurt and (from the mid-sixteenth century only) Quedlinburg. Both cities were struck by severe plagues in this period, whose timing coincides fairly well with their respective decline in inequality (Jütte 1984, p. 57; Wozniak 2013, pp. 137-56).

Despite a couple of outliers, our data strongly support the view that the sixteenth century was a period of rising inequality in cities. This tendency is even clearer if we look at rural areas as, notwithstanding some shortterm fluctuations, wealth inequality was higher everywhere at the end of the sixteenth century than it was at the beginning and sometimes the increase was substantial.

\footnotetext{
16 The ability of immigration of relatively poor individuals and households to increase wealth inequality has been confirmed by the few available micro-studies of post-plague distributive and demographic dynamics (Alfani 2010a, pp. 540-41, 2010b, pp. 67-70).
} 


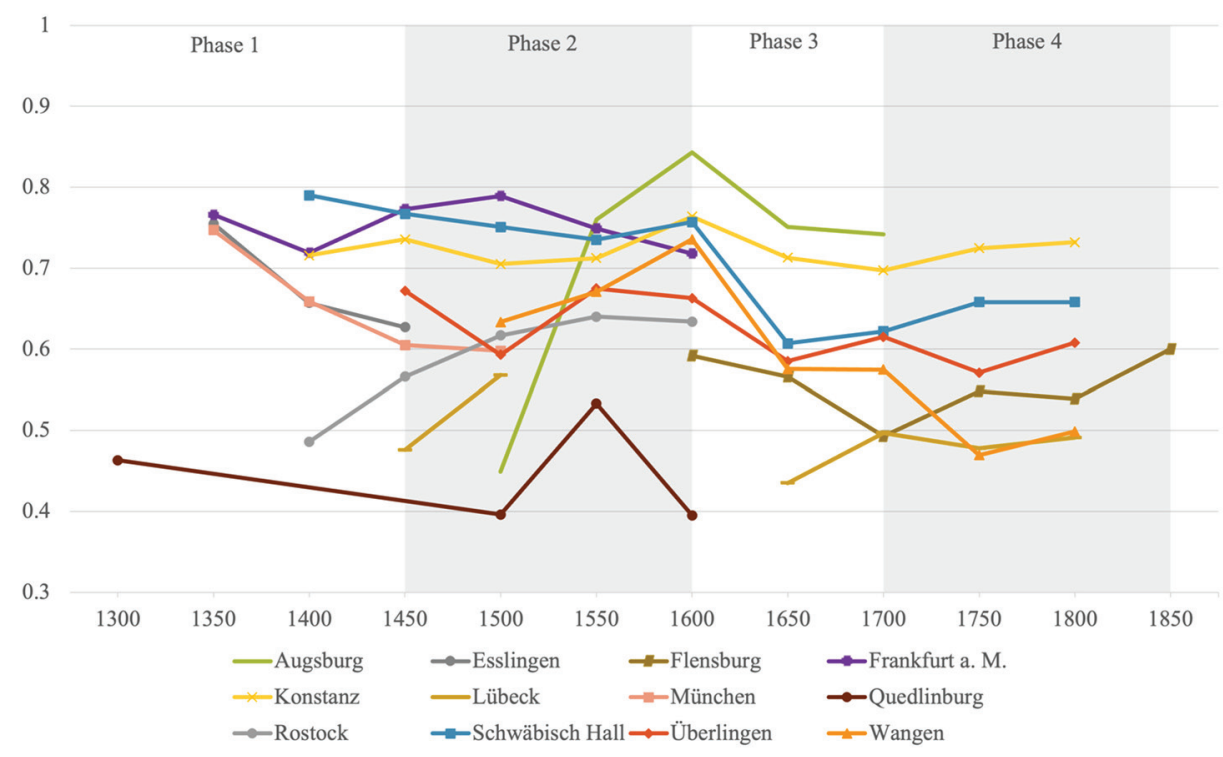

FIGURE 2

LONG-TERM TRENDS IN ECONOMIC INEQUALITY IN URBAN GERMANY, 1300-1850 Sources: See the main text.

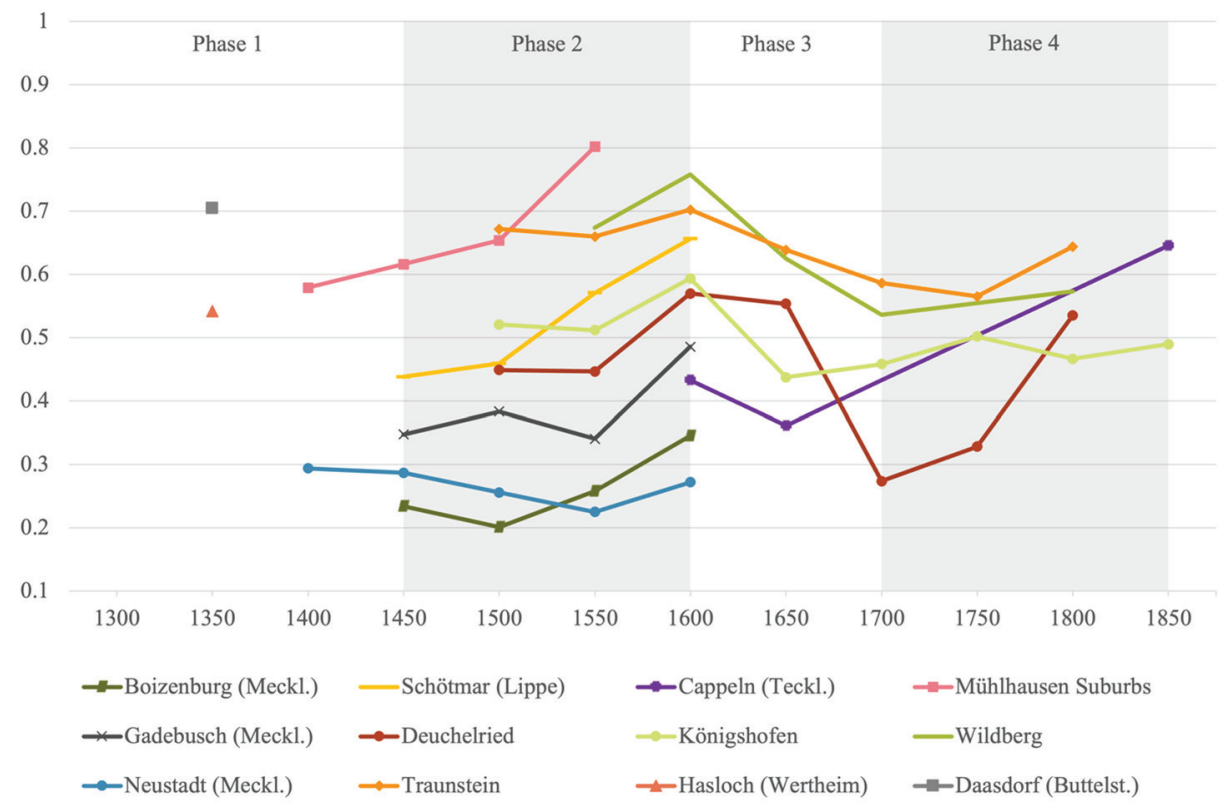

FIGURE 3

LONG-TERM TRENDS IN ECONOMIC INEQUALITY IN RURAL GERMANY, 1300-1850 Sources: See the main text. 


\section{Phase 3: The Thirty Years' War and Its Aftermath}

The third phase, from circa 1618 to circa 1700 , was strongly influenced by the Thirty Years' War (1618-1648). This phase is characterized by declining wealth inequality across all cases in our sample, both urban and rural, reversing the trend in phase 2. Although the decline was particularly steep in the first half of the century, when the Thirty Years' War was in full swing, many localities experienced inequality reduction in the following crisis-ridden decades as well. All communities in our database were affected by the war, but its impact varied by region. The most affected territories were Pomerania, Mecklenburg, Thuringia, Hesse, and Württemberg, whereas the least directly affected territories were the Austrian Duchies and parts of the northwest of the Holy Roman Empire (Whaley 2013a, p. 633). This is reflected in our sample, as cities such as Augsburg, Schwäbisch Hall, Überlingen, and Wangen, all of which suffered because of military occupation, show a particularly substantial drop in inequality during the first half of the century. We can reach similar conclusions looking at the rural areas. For example, the modest inequality decline reported for Tecklenburg, located in northwestern Germany which was less affected by the war, is in stark contrast to Königshofen, Wangen, and the surrounding villages. In these areas, which are known to have suffered grievously (Whaley 2013a, p. 633; von Hippel 2009), we find large-scale inequality reduction. For example, in Königshofen the Gini index dropped from 0.594 in 1601 to 0.437 in 1664 .

\section{Phase 4: The End of the Holy Roman Empire and the Beginning of Industrialization}

The fourth phase, covering the period from circa 1700 to circa 1850 , is characterized by an increase in inequality, marking a reversal from the trend in phase 3 . This period was defined by further state consolidation, particularly in Brandenburg-Prussia and Habsburg-Austria (Whaley 2013b, pp. 348-51). This was followed by drastic changes in the political landscape: in 1806, the Empire dissolved and most territories re-grouped in the German Confederation in 1815 (Whaley 2013b, pp. 646-50). Another major change during this period was the beginning of industrialization, which in this part of Europe took hold from around 1840, with some regions experiencing early industrialization from about 1780 (Ogilvie 1996a, p. 121).

Notwithstanding the magnitude of these economic and political changes, the increase in inequality during this period is rather modest in 
cities. In Wangen inequality even declined in the first half of the century, later experiencing very limited growth. However, in rural areas, there was a pronounced increase in inequality, except for Königshofen where it was more limited. Wealth inequality growth was particularly intense in the villages of Deuchelried and Niederwangen where the Gini increased from 0.274 and 0.332 respectively in 1700 to 0.535 and 0.392 in 1800 .

Before proceeding, we need to mention one further relevant conclusion from our case-by-case analysis: across time, inequality levels tended to be higher in cities than in rural areas. This empirical finding has also been reported in studies of other European areas, such as Tuscany (Alfani and Ammannati 2017, p. 1084) and Holland (Van Zanden 1995, p. 649), as well as for the German region of Hesse-Kassel during the nineteenth century (Wegge 2021). This is an additional reason why we will also discuss aggregate reconstructions for cities and rural areas separately.

\section{INEQUALITY IN PREINDUSTRIAL GERMANY: AN AGGREGATE ESTIMATE}

This section focuses on the trends in wealth inequality in the whole of Germany using the method described previously. We validate whether the aggregate figures support our characterization of a four-phase development of German inequality from the Black Death until the beginning of industrialization. Moreover, we discuss the likely mechanisms behind the observed trends and the plausibility of some of the prevailing theories about preindustrial inequality change in Germany. Finally, Germany's inequality trajectory is compared with other European regions.

\section{Wealth Inequality in Germany, 1350-1850}

Figure 4 and Table 2 report our series of wealth inequality estimates for Germany as a whole, which are the main contributions of this article. We also report 95 percent confidence intervals calculated by employing a bootstrap technique. ${ }^{17}$ The overall trend is in line with the evidence from our case-by-case analysis (compare with Figures 2 and 3 ). Germany started from a relatively high level of wealth inequality in 1350 , with a Gini of 0.662 , and experienced an overall decline following

\footnotetext{
${ }^{17}$ The bootstrap technique consists of repeated resampling with random draws with replacement from the original distribution. Consequently, it allows us to check the robustness of our estimates against imprecise wealth assessments, as well as against sampling issues in the composition of an "aggregate" distribution. See Online Appendix 6 for further technical discussion and Steckel and Moehling (2001) for an example of application.
} 
the Black Death. This decline in inequality lasted until about the midfifteenth century, when a secular minimum in the Gini level was reached, at 0.562. This result is consistent with Abel's (1976) and Rodepeter's (1998) conjectures about income inequality. Indeed, a decline in both wealth and income inequality after the Black Death seems to have been a pan-European phenomenon (Alfani and Murphy 2017; Scheidel 2017; Alfani 2021, 2022). This important finding is worthy of some further discussion.

The Black Death killed approximately half the German population, and local mortality rates were sometimes substantially higher (Rodepeter 1998, p. 5; Wilson 2017, p. 494). Both cities and rural areas were affected, which is confirmed by our urban and rural series in Figure 4, both showing inequality reduction from 1350. Importantly, the Black Death left physical capital, such as real estate, intact, damaging human capital instead. This had several consequences that help to explain why the pandemic led to a lower concentration of wealth. First, the scarcity of manpower led to the higher marginal productivity of labor. This drove up wages for the surviving workers in urban crafts and agriculture. Secondly, rising wages came alongside falling prices of real estate as its supply outstripped demand. Consequently, depopulation enabled the poor to take over empty real estate and to enlarge their plots (Abel 1976, p. 66; Rösener 1996, pp. 65-66; Rodepeter 1998, pp. 7-12). ${ }^{18}$ Thirdly, there was a power shift that saw a weakening of the feudal lords relative to the peasants and thus a reduction of their rent extraction. The peasants' feudal burdens were reduced and their rights improved since they were in a good position to negotiate with the landowners, who needed a workforce for their empty fields. Importantly, this relative weakening of seignorial power happened in regions to the west of the Elbe river only, the area most represented in our database. East of the Elbe the Black Death had the opposite effect, leading to higher contributions and more compulsory services to be provided by the peasants (Scott 2002, pp. 153-60; Jenks 2005, p. 49; Ogilvie 2014). More generally, across Western Europe labor became scarce in the aftermath of the Black Death, and for a period workers enjoyed a much stronger bargaining power (see Alfani 2022 for a synthesis). All these mechanisms jointly led to inequality decline.

The post-Black Death low point was reached around 1400 (slightly later for cities), after which a long phase of rising inequality followed. Overall wealth inequality peaked at a Gini of 0.661 around 1600 . This

\footnotetext{
${ }^{18}$ Evidence from Lower Saxony and Hesse suggests that villages could expand their lands by approximately 100 to 275 percent (Moraw 1989, p. 269).
} 


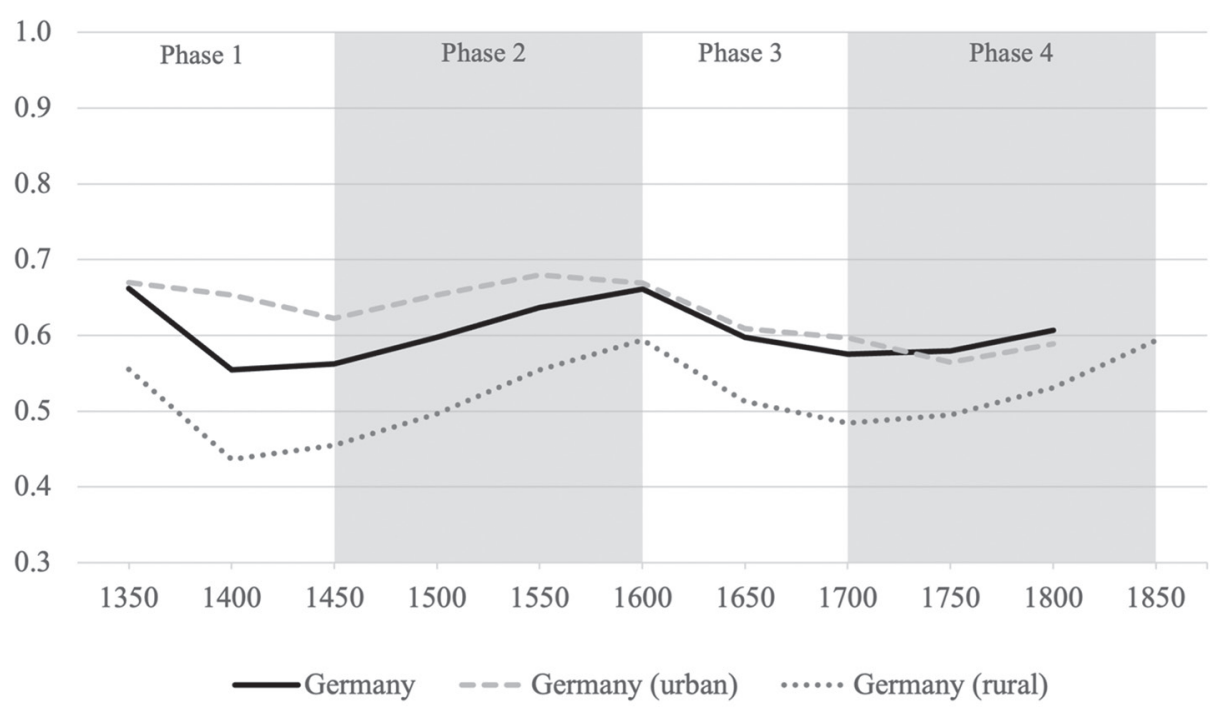

FIGURE 4

LONG-TERM TRENDS IN ECONOMIC INEQUALITY IN GERMANY (GINI INDEXES)

Notes: In most instances the inequality estimates for Germany as a whole will fall between the urban and the rural estimates simply because cities tend to be more unequal than villages. However, this is not a statistical necessity - see Online Appendix 6 for details regarding the estimation procedure. The reason is that regional inequality also depends upon the urban-rural differential in average household wealth, which is an important source of overall inequality. So, when cities experience a period of relatively low inequality it might be that the regional estimates temporarily exceed the urban ones. In our case, this happens during 1750-1800.

Sources: See the main text.

result suggests that the late Middle Ages and the first part of the early modern period were a phase of growing inequality, eventually interrupted by the outbreak of the Thirty Years' War. The historical literature hints at three possible mechanisms that could explain this pattern: economic growth (Scheidel 2017, p. 335), demographic expansion (Pfister 2020), and inegalitarian resource extraction by special-interest groups and public authorities (Pfister 2019, p. 242; Ogilvie 1992, pp. 426, 429-34). Our data do not allow us to test which of these arguments best explain Germany's inequality pattern. However, economic growth does not appear to be a plausible candidate: the available data on GDP per capita show that Germany experienced a substantial economic decline during the sixteenth century, placing it clearly on the losing side of the so-called "Little Divergence" between North and South Europe (Pfister 2011; Broadberry et al. 2015, p. 423).

There is some evidence that rising inequality had already started to level off in cities from ca. 1550 (Figure 4). This could be related to specific, local pre-war crises. From the late sixteenth century onwards, Europe's 
TABLE 2

ECONOMIC INEQUALITY IN GERMANY, C.1350-1850 (GINI INDEXES. 95\% CONFIDENCE INTERVALS IN BRACKETS)

\begin{tabular}{|c|c|c|c|c|}
\hline & Urban Germany & Rural Germany & $\begin{array}{l}\text { Germany } \\
\text { (Overall) }\end{array}$ & $\begin{array}{c}\text { Germany } \\
\text { (Overall, Propertyless } \\
\text { Included) }\end{array}$ \\
\hline 1350 & $\begin{array}{c}0.670 \\
(0.627-0.714)\end{array}$ & $\begin{array}{c}0.555 \\
(0.511-0.599)\end{array}$ & $\begin{array}{c}0.662 \\
(0.645-0.679)\end{array}$ & $\begin{array}{c}0.690 \\
(0.673-0.708)\end{array}$ \\
\hline 1400 & $\begin{array}{c}0.654 \\
(0.626-0.681)\end{array}$ & $\begin{array}{c}0.437 \\
(0.381-0.493)\end{array}$ & $\begin{array}{c}0.555 \\
(0.537-0.572)\end{array}$ & $\begin{array}{c}0.559 \\
(0.541-0.577)\end{array}$ \\
\hline 1450 & $\begin{array}{c}0.623 \\
(0.593-0.652)\end{array}$ & $\begin{array}{c}0.455 \\
(0.409-0.500)\end{array}$ & $\begin{array}{c}0.562 \\
(0.554-0.571)\end{array}$ & $\begin{array}{c}0.569 \\
(0.560-0.578)\end{array}$ \\
\hline 1500 & $\begin{array}{c}0.653 \\
(0.637-0.669)\end{array}$ & $\begin{array}{c}0.496 \\
(0.477-0.516)\end{array}$ & $\begin{array}{c}0.598 \\
(0.593-0.603)\end{array}$ & $\begin{array}{c}0.604 \\
(0.601-0.607)\end{array}$ \\
\hline 1550 & $\begin{array}{c}0.680 \\
(0.658-0.702)\end{array}$ & $\begin{array}{c}0.555 \\
(0.527-0.582)\end{array}$ & $\begin{array}{c}0.637 \\
(0.629-0.646)\end{array}$ & $\begin{array}{c}0.668 \\
(0.659-0.676)\end{array}$ \\
\hline 1600 & $\begin{array}{c}0.669 \\
(0.649-0.690)\end{array}$ & $\begin{array}{c}0.594 \\
(0.573-0.615)\end{array}$ & $\begin{array}{c}0.661 \\
(0.651-0.672)\end{array}$ & $\begin{array}{c}0.675 \\
(0.665-0.684)\end{array}$ \\
\hline 1650 & $\begin{array}{c}0.609 \\
(0.579-0.638)\end{array}$ & $\begin{array}{c}0.513 \\
(0.481-0.544)\end{array}$ & $\begin{array}{c}0.598 \\
(0.592-0.604)\end{array}$ & $\begin{array}{c}0.619 \\
(0.613-0.625)\end{array}$ \\
\hline 1700 & $\begin{array}{c}0.597 \\
(0.563-0.630)\end{array}$ & $\begin{array}{c}0.484 \\
(0.455-0.513)\end{array}$ & $\begin{array}{c}0.575 \\
(0.568-0.583)\end{array}$ & $\begin{array}{c}0.589 \\
(0.581-0.597)\end{array}$ \\
\hline 1750 & $\begin{array}{c}0.565 \\
(0.532-0.598)\end{array}$ & $\begin{array}{c}0.495 \\
(0.457-0.533)\end{array}$ & $\begin{array}{c}0.580 \\
(0.572-0.587)\end{array}$ & $\begin{array}{c}0.597 \\
(0.590-0.604)\end{array}$ \\
\hline 1800 & $\begin{array}{c}0.589 \\
(0.555-0.623)\end{array}$ & $\begin{array}{c}0.531 \\
(0.488-0.574)\end{array}$ & $\begin{array}{c}0.607 \\
(0.599-0.615)\end{array}$ & $\begin{array}{c}0.617 \\
(0.609-0.624)\end{array}$ \\
\hline 1850 & & $\begin{array}{c}0.593 \\
(0.555-0.632)\end{array}$ & & \\
\hline
\end{tabular}

Notes: $95 \%$ confidence intervals have been produced by means of bootstrap techniques. The aggregate wealth distributions have been produced with the method introduced by Alfani (2015). See Online Appendix 6 for details.

Sources: See the main text.

economic center of gravity shifted away from the Mediterranean to the new Atlantic trade routes dominated by England and the Netherlands. As a consequence, former important trading posts such as Erfurt, Lübeck, and some of the great south German trading cities lost much of their clout. This coincided with the bankruptcy of a number of trading firms, involving rich merchants who were additionally strained by several state bankruptcies in Spain and France (Gömmel 1998, pp. 1-6; Scott 2002, pp. 115-32). These processes could have reduced inequality by curtailing the wealth of the richest part of the population in some urban settings, but not in rural areas.

Throughout the crisis-ridden seventeenth century and especially during the Thirty Years' War (1618-1648) inequality declined in Germany, reaching its early modern low in 1700 with a Gini of 0.575 . It is important 
to clarify that although the inequality-reducing effects of the Thirty Years' War were expected (based on earlier literature), this conflict remains an exception because medieval and early modern wars did not usually lead to inequality reduction, in Germany or elsewhere.$^{19}$ In contrast to other preindustrial wars, the Thirty Years' War had immense and exceptional spill-over effects, connecting several "egalitarian" factors in one event: widespread physical destruction, commercial and productive breakdown, and famine and death by the plague that selectively hit the poor. Each of these components requires some further discussion.

The Thirty Years' War was the most ravaging conflict of early modern Europe. It saw large-scale destruction or confiscation of financial capital, real estate, food reserves, and productive assets such as agricultural livestock (Redlich 1959; Van Zanden 1995, p. 646; Wilson 2009, pp. 783-806; Scheidel 2017, pp. 338-39). Additionally, the war led to a breakdown of market exchange and production. This was due partly to the loss of commercial capital, but also the interruption of trade routes and the long-lasting, highly insecure economic situation played a role. Consequently, commercial activity and production, especially in the agricultural sector, plummeted. Widespread bankruptcy ensued (Röck 1989, pp. 941-43; Wilson 2009, pp. 795-801). These developments continued to weigh heavily on the German economy beyond the actual war in what is known as the general crisis of the seventeenth century (Ogilvie 1992).

The ravages of war and economic breakdown could have led to inequality reduction by curtailing the wealth of the economic elites. However, they could also have reduced inequality simply because they led to mass mortality. In fact, the decline in market exchange and production coincided with harvest failures and led to widespread famine. This might have facilitated the diffusion of plague by roving soldiers throughout Germany. In particular, during 1627-1629 Germany was affected by the worst plague since the Black Death. Plague and famine together led to a population decline of about 40 percent (Eckert 1996; Outram 2001). This demographic catastrophe favored inequality reduction through two distinct channels: first, by reducing the price of agricultural goods and land, and by increasing marginal productivity of labor and therefore labor income (Pfister 2020), which would be similar to what happened after the Black Death. Secondly, famine and plague were socially selective: poor people were more likely to die due to the specific socio-economic conditions created by the war (Outram 2001; Scheidel 2017, p. 338). It seems entirely possible that in the case of the seventeenth-century

${ }^{19}$ See Schaff (2020) for some econometric evidence and a discussion of why wars in preindustrial Germany were rarely destructive enough to reduce inequality. 
plagues the second channel prevailed, similarly to what has been argued for other European areas, for example, the Republic of Venice (Alfani and Di Tullio 2019, p. 119). This might have differentiated the redistributive dynamics associated with the Black Death and with the seventeenth-century plagues: in the case of the first, large-scale redistribution towards the poor occurred, but after the second, extermination of the poor prevailed, as has been pointed out by Alfani (2022).

It is difficult to disentangle the distributive impact of war, famine, and plague in this period. Additionally, while population dynamics surely played a role, we believe that the evidence is not consistent with a demographic explanation of inequality decline during the Thirty Years' War such as that proposed by Pfister (2020). Instead, the decline in wealth inequality experienced by seventeenth-century Germany was so intense and long-lasting because it resulted from a more complex interaction of several war-related mechanisms, together affecting both the top and the bottom of the distribution. This view finds support in a comparison of Germany with the case of the Sabaudian State (Piedmont) in northwestern Italy. This state was located just on the other side of the Alps and was even represented at the diet of the Holy Roman Empire (Reichstag). The Sabaudian State was affected by exactly the same plague wave that ravaged Germany. The plague entered north Italy at the end of 1629, and during 1630 it caused the death of about 35 percent of the overall population (Alfani 2013a): not far from the 40 percent reported for Germany. However, the Sabaudian State was only marginally affected by war in those years (the main conflict was the War of the Mantuan Succession of 1628-1631, fought mostly beyond the state boundaries). Consequently, while the plague might have affected the poor in ways not dissimilar from Germany, other "egalitarian" factors involving the top of the distribution, such as the destruction of capital or the wide-ranging breakdown of commercial activity and agricultural production, were mostly absent. Indeed, unlike in Germany, inequality continued to grow in Piedmont throughout the seventeenth century (Alfani 2015, pp. 1080-84). Even though there is some evidence of local plague-induced drops in inequality, they were of limited size and very short-lived (Alfani 2010b).

Additional support for the view that the Thirty Years' War was able to lead to inequality decline only because of its truly exceptional scale and because it interacted with widespread famine and plague comes from a comparison with the other major wars affecting preindustrial Germany. None of these, including the German Peasants' War of 1524-1525, which was very violent and killed about 100,000 people in only two years (Wilson 2017, p. 593), seem to have left even a trace in our series. 
From around 1700, inequality rose again. This development continued until the end of the early modern period. For the rural areas, we have evidence of inequality growth until around 1850, when the Gini index, at 0.593 , reached again the secular maximum that it had briefly touched on the eve of the Thirty Years' War. In cities, inequality stagnated throughout the eighteenth century with signs toward growth from the mid-century only. Note that the overall tendency across Germany reflects more closely the dynamics characteristic of the rural areas because the vast majority of the population was rural. Also note that our inequality estimates for 1800-1850 are basically in line with the estimates reported by Wegge (2021) for the principality of Hesse-Cassel, where ca. 1850 the Gini calculated on landholding sizes stands at 0.615 .

There are several plausible explanations for this overall tendency toward inequality growth in eighteenth- and early nineteenth-century Germany. Firstly, it has been argued that, as during the sixteenth century, population growth led to inequality growth (Pfister 2020). Secondly, the increase in industrial production might have contributed to rising inequality (Kocka 1990, pp. 117-20). This explanation points to higher wages of skilled workers and large profits as drivers of inequality during early industrialization (Kuznets 1955; Ray 1998, pp. 209-11). The explanation also meshes well with accounts of the gradual growth of industrial production from the late seventeenth century, especially in rural areas (Gewerbelandschaften) (Ogilvie 1996a).

While in principle both these arguments are compatible with our data, earlier literature on Germany has failed to consider another factor which has recently been proposed as a cause of inequality growth in early modern Europe: the rise of the fiscal-military state. According to this theory, states in early modern Europe increasingly extracted and redistributed economic resources in ways that promoted inequality growth, mainly because of increases in per-capita taxation in the context of regressive fiscal systems (Alfani and Di Tullio 2019; Alfani 2021). In Germany, state formation is usually considered to have been a longrun, indirect consequence of the Thirty Years' War, accelerating in the major territories from the end of the early modern period (Ogilvie 1996b, p. 266; Schilling 1994, p. 21). ${ }^{20}$ Although Germany might have been affected by increases in regressive taxation at the state level later than other European areas, the fact remains that state formation might help to explain the observed final phase of inequality growth.

${ }^{20}$ Note on state formation that most territories could not establish themselves in terms of fiscal and military administration until the end of the early modern period (Volckart 2002, pp. 163-65). 


\section{Robustness Checks and Additional Insights}

Our conclusions about the overall trends in wealth inequality across Germany can be further strengthened by a series of robustness checks (additional technical details in Online Appendix 6). We begin by applying an alternative method to confirm the reliability of our findings. We adapted the regression-based approach introduced by Clark (2005) to our case and we applied it to the panel of local Gini indexes introduced in the previous section. We estimated a linear regression of the following form:

$$
\operatorname{Gini}_{i, t}=\alpha_{i}+\sum_{\tau=1350}^{1800} \beta_{\tau} \text { Year }+\varepsilon_{i, t}
$$

Our dependent variable is the Gini coefficient in locality $i$ in year $t(1350$ to 1800 , in steps of 50 years); $\alpha_{i}$ is a full set of locality fixed effects, which capture time-invariant locality-specific characteristics. Our main interest is to estimate the parameters on the Year-dummies (1350 to 1800) to derive average Gini change. The omitted reference category is the year 1600 , when we have the greatest number of observations.

This estimation resulted in a "dimensionless index," in other words, an index that only reports increases or decreases in inequality relative to the benchmark year 1600 . Using the Gini index of 1600 calculated with our original aggregation method to anchor the dimensionless index, we arrive at an alternative set of Gini estimates. The result from this alternative estimation is shown in Figure 5, where it is compared with our preferred estimates. The robustness check confirms that the trend in wealth inequality discussed earlier is not an artificial product of our preferred reconstruction method. Indeed, when the same Gini is assumed for 1600 the alternative estimates are within, or bordering with, the 95 percent confidence intervals calculated on our aggregate distributions over the whole period. ${ }^{21}$

\footnotetext{
${ }^{21}$ The regression method seems to slightly overestimate Gini levels after the Black Death with respect to our preferred method, and underestimate Gini levels after the Thirty Years War. These non-systematic differences in the results-first overestimation, then underestimationderive from the entirely different nature of the methods. The regression method averages the trends across the communities. Instead, our preferred method shows the change in one overall distribution of all sampled localities. There is no theoretical reason to believe that average change in communities and change in an overall distribution must coincide. Moreover, as the regression-based method requires panel data, we do not use rural data for the estimates during 1350-1400. Given these essential differences in the methods, we find it remarkable and quite encouraging that they lead to the exact same trend and very close estimated inequality levels.
} 


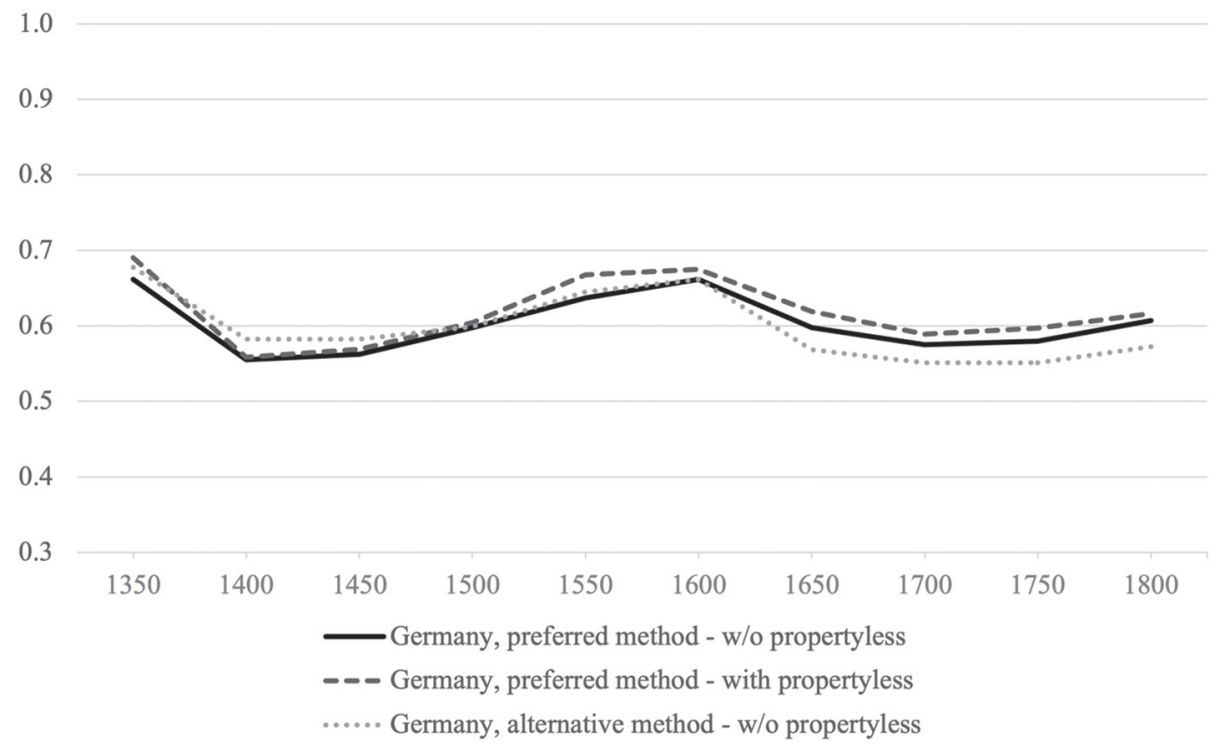

FIGURE 5

INEQUALITY IN GERMANY: PREFERRED VS. ALTERNATIVE ESTIMATES

Sources: See the main text.

One shortcoming of our overall reconstruction is that it excludes the propertyless, and one might conclude that this leads to a significant underestimation of wealth inequality. To quantify this bias, we aggregated the available information on the propertyless in order to produce some tentative estimates of their prevalence over time. Since the term "propertyless" can cause confusion, we underline that this category should not be confused with that of "the poor." Poor people were always included in tax registers and are therefore included in our distribution. The propertyless are more properly understood as a subgroup of the poor-indeed, as the poorest of the poor: they had no taxable wealth whatsoever or fell below the threshold for taxation (Scott 2002, pp. 44-45). Here we are not making any further claim about the nature of the propertyless, save for arguing (based on our archival sources) that they are the only category that is usually entirely absent from our distributions. ${ }^{22}$

We estimated that during the early modern period the propertyless were only a small percentage of the German population, ranging from a low of 0.81 percent in 1400 to a high of 8.4 percent in 1550 . Based

22 A recent literature has argued that lacking other information, the prevalence of the propertyless can be used as a rough proxy for absolute poverty (Alfani 2020; Alfani, Ammannati, and Ryckbosch 2020). 
on these estimates, we added to our aggregate distributions the corresponding number of extra elements, all set at zero wealth, and recalculated our inequality measures. As reported in Table 2 and Figure 5, adding the propertyless leads to only slightly higher Gini levels: our measures increase by a minimum of 0.004 points in 1400 to a maximum of 0.03 points in 1550 . Importantly, the overall trend does not change and becomes even more pronounced during the early modern period. This result is even more significant considering that not all those "propertyless" were entirely destitute. At least some of them had wealth above zero- but remained below the threshold for taxation. Consequently, the series including them should be understood as an upper boundary to the "real" level of wealth inequality across Germany.

\section{Germany and Europe: A Comparison}

We now focus on the path followed by Germany in relation to other European areas. In Figure 6, Germany is compared to those areas for which similar reconstructions are available. The overall trends in wealth inequality that we have detected match quite closely those found elsewhere with one important exception: the phase of inequality decline covering the seventeenth century, which is not reported elsewhere. In particular, until 1600 both levels and trends match those found for Italy and especially for the Sabaudian State quite well, but only a century later Germany was comparatively much more egalitarian. Note that levels of inequality between Germany and Italy are of broadly comparable nature because for both areas the series refer to wealth, while those for the Low Countries refer to income inequality (which is usually lower than wealth inequality, in the past as today). Consequently, with respect to the Low Countries only the trends, not the levels, should be compared (Alfani and Ryckbosch 2016). The same point could be made for England, for which estimates of income inequality produced with a different method (social tables) confirm the picture of growing inequality from the late fourteenth to the late seventeenth century and beyond (Broadberry et al. 2015, p. 329; Alfani 2021). Figure 6 also suggests that without the decline in inequality during the seventeenth century, Germany might have found itself, by the mid-eighteenth century, in a much more unequal scenario - indeed, had it followed an "Italian" path after 1550 or 1600, its Gini index would have been $0.1-0.2$ points higher (compare the Gini of 0.607 we reconstructed for 1800 Germany to the 0.782 found for the Sabaudian State or the 0.856 found for the Florentine State in 1750). 


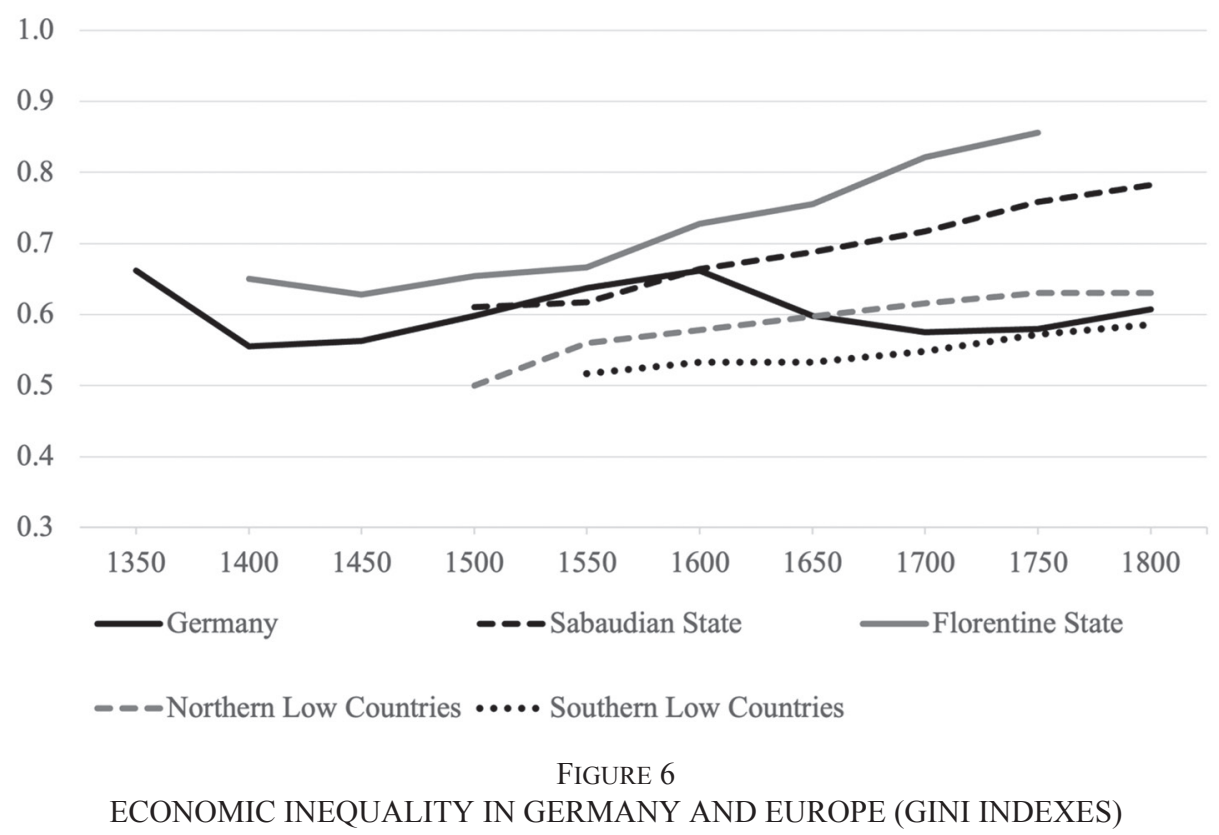

Notes: The series refer to wealth inequality for Germany, the Sabaudian State, and the Florentine State, and to income inequality for the Low Countries.

Sources: See the main text.

Germany followed a path similar to that of other European regions throughout the period, bar for the seventeenth century. Then, an exceptional event (the Thirty Years War, in combination with the worst plague since the Black Death) triggered a phase of inequality decline that has not been observed for any other European area so far. This interrupted a tendency toward inequality growth that otherwise could have been reasonably expected to continue undeterred.

The view that the Thirty Years' War had a direct impact upon German inequality can be further supported by an empirical test. Table 3 reports difference-in-differences estimates of the effect of the Thirty Years' War in Germany. As a counterfactual, we take the only European region integrated into the structures of the Holy Roman Empire but not exposed to the Thirty Years' War and for which comparable inequality data exist: the Sabaudian State. ${ }^{23}$ We code all our communities in Germany as "treated" and all communities in the Sabaudian State as "non-treated," with the

\footnotetext{
${ }^{23}$ Until 1797, the Sabaudian State had a seat at the imperial diet, was part of the upper Rhenish imperial circle (Oberrheinischer Reichskreis), and accepted jurisdiction of the Empire's supreme court (Reichskammergericht) (Wilson 2009, pp. 119, 194, 227). This makes the Sabaudian the most suitable counterfactual for our analysis.
} 
TABLE 3

THE LEVELING EFFECT OF THE THIRTY YEARS' WAR: A DIFFERENCE-IN-DIFFERENCES ESTIMATE

\begin{tabular}{lcccc}
\hline \hline & $(1)$ & $(2)$ & $(3)$ & $(4)$ \\
& Gini & Gini & Gini & Gini \\
\cline { 2 - 5 } & $1500-1700$ & $1500-1700$ & $1500-1700$ & $1500-1800$ \\
\hline 30 -Years' War × Post & $-0.135^{* * *}$ & $-0.176^{* * *}$ & $-0.160^{* * *}$ & $-0.143^{* * *}$ \\
& $(0.021)$ & $(0.031)$ & $(0.029)$ & $(0.025)$ \\
Log-population & & & $0.072^{*}$ & 0.030 \\
& & & $(0.040)$ & $(0.021)$ \\
Locality FE & Yes & Yes & Yes & Yes \\
Time FE & Yes & Yes & Yes & Yes \\
Locality time-trends & No & Yes & Yes & Yes \\
Adjusted $R$-squared & 0.417 & 0.677 & 0.696 & 0.743 \\
Observations & 148 & 148 & 148 & 198 \\
\hline
\end{tabular}

Notes: Estimation method is OLS. Robust standard errors clustered at the community level in parentheses. ${ }^{* * *} \mathrm{p}<0.01, * * \mathrm{p}<0.05, * \mathrm{p}<0.1$.

Sources: See the text and Online Appendix 7.

post-treatment period beginning in $1650 .{ }^{24}$ Additional technical details are provided in Online Appendix 7.

The identifying assumption is: communities that were "treated" by the Thirty Years' War would have experienced a similar inequality development to communities that were "not treated," had the war not happened. Figure 6 shows that Germany and the Sabaudian State followed a similar inequality development until the outbreak of the Thirty Years' War. This provides visual evidence for the common-trend assumption (Angrist and Pischke 2009, pp. 231-33). To measure the effect of the Thirty Years' War on inequality we estimate this linear specification:

$$
\text { Gini }_{i, t}=\alpha_{i}+\pi_{t}+\beta\left(30 Y W_{i} \times \text { Post }_{t}\right)+\delta \ln \left(P_{i, t}\right)+\text { Trend }_{i}+\varepsilon_{i, t}
$$

${ }^{24}$ The Thirty Years' War affected almost all of the territory of modern Germany (exception made for a few lucky places, like Hamburg, not included in our database). Yet several regions within the wider Holy Roman Empire were almost unaffected, such as Austria, Tirol, Switzerland, and the Sabaudian State (see Franz 1961, p. 8; Barbero 2008). Preindustrial Europe was constantly exposed to warfare (Tilly 1992, p. 72), and we are not claiming that the Sabaudian State was entirely peaceful during this period. In particular, it was involved in the War of the Mantuan Succession (1628-1631), but its impact on local inequality levels was if at all modest (see Figure 6) because the war was waged mostly beyond the state boundaries and because a negotiated settlement could be reached (Wilson 2009, pp. 457-58, 649). With the partial exception of this episode, the Sabaudian State - as Italy in general — was spared from the great wars of the first half of the seventeenth century (Alfani 2013b, p. 22). Additionally, even if warfare in the Sabaudian State had some limited inequality-reducing effects, this would bias the estimates in Table 3 toward a smaller effect of the Thirty Years' War, so our main conclusion would be confirmed regardless. 
Our dependent variable is the Gini coefficient in locality $i$ in year $t(1500$ to 1700 or 1800 , in steps of 50 years). The interaction of the treatmentstatus indicator $\left(30 \mathrm{YW}_{i}\right)$ and the post-treatment indicator ( Post $\left._{t}\right)$ provides the coefficient of interest; $\alpha_{i}$ and $\pi_{t}$ are full sets of locality and time fixed effects. To address concerns about unobserved time-varying localityspecific characteristics, we modify the benchmark model to include locality-specific time trends $\left(\right.$ Trend $\left._{i}\right)$. We also control for a locality's population size $P$ (in logarithm).

Our baseline estimates in Column (1) and the more stringent specification in Column (2) suggest that the war reduced wealth inequality in German communities on average by about 0.135 to 0.176 Gini points. This is a sizeable effect compared to the inequality levels reported in Table 2. If we control for population size of communities (Column (3)) the effect gets smaller, but it still remains sizeable. Column (4) indicates that the effect of the war persisted, as communities in Germany were significantly less unequal even when considering the period until 1800 .

Germany's seventeenth-century divergence from the path followed by other European regions is hardly surprising if we consider the exceptional impact of the Thirty Years' War in this area. This is clear in comparison to Italy, which in Braudel's words was only "slightly scratched" by the conflict (Braudel 1986, p. 37; Alfani 2013b, p. 41), but overall this is valid for the Low Countries as well. Deaths among the military were much more numerous in the German area than in the Low Countries (compare, e.g., Clodfelter 2017, pp. 36-41) and the same holds for deaths among the civilian population, especially when considering the famines and epidemics that the war had induced or at least had favored. A confirmation comes from estimates of overall population change: by 1700 , the German population remained 13 percent lower than in 1600, while the Dutch had grown by one-third (Alfani 2013a, pp. 411, 424).

After 1700, Germany re-joined the European fold and returned to a path of continuous inequality growth, although starting from levels lower than those typical of other parts of the continent. Additional research, especially on the nineteenth-century distributive dynamics, would be required to fully grasp the possible implications of this German specificity. This, however, is beyond the scope of this article. ${ }^{25}$

\footnotetext{
${ }^{25}$ It would also be informative to explore whether differences in inheritance practices or agricultural institutions (Wegge 2021; Ogilvie 2014) led to variation in inequality levels between specific German regions.
} 


\section{CONCLUSION}

This article has provided an overview of long-term inequality trends in preindustrial Germany. By using a novel database of wealth inequality we were able to estimate inequality trends over five centuries (from ca. 1350 to 1850). This allowed us to document four alternating phases of inequality decline and growth.

The first phase of inequality decline was triggered, as elsewhere in Europe, by the Black Death of 1347-1352 and it lasted until ca. 1450. After this temporary calm in inequality, the trend turned toward growth again. Throughout the eventful sixteenth century, the time of the Protestant Reformation and religious wars, Germany experienced steadily rising inequality. Inequality reached its high point on the eve of the Thirty Years' War (1618-1648). Subsequently, we find the second phase of significant inequality decline, triggered by this exceptionally destructive war and the widespread plague it brought with it in 1627-1629. This second phase of inequality decline is particularly important, as it distinguishes Germany from other European areas for which we have studies of longterm inequality trends. Indeed, from Italy to the Low Countries inequality growth was found to be monotonic throughout the early modern period, but in Germany, inequality growth resumed only from ca. 1700 onward. This interruption of inequality growth seems to have led eighteenthcentury Germany to become, for a period at least, relatively egalitarian if compared both to its previous state in the sixteenth century and to other European regions in the eighteenth century. The implications of this will be the object of future research.

Our findings of the leveling power of large-scale catastrophes are particularly relevant in the view of recent literature about the drivers of inequality in the long run of history. While for the Black Death we confirm that Germany took part in a broader European process (see Alfani 2022 for a synthesis), regarding the Thirty Years' War, we are the first to provide strong support for the potential of early modern wars to reduce inequality. In general, this confirms Scheidel's (2017) hypothesis about the leveling power of catastrophes. However, the Thirty Years' War was unique in its level of destruction and its high mortality, further boosted by the associated famines and plagues. These characteristics make it the only pre-industrial war for which we have evidence of a significant and long-lasting "egalitarian" impact on inequality. Consequently, this finding supports the view that we need to be very cautious when making generalizations about preindustrial distributive dynamics (Alfani 2021, 2022), and that we need more regional- or state-level studies to highlight commonalities as well as local specificities. 
The picture that emerges from the case of Germany is indeed one of a succession of distributional waves, which supports the arguments put forward by Milanovic (2016, pp. 50-53), including his view that the events triggering phases of inequality decline were of an "idiosyncratic" nature. But at the same time, had those events not occurred, and had Germany continued along a path orientated toward inequality growth throughout the early modern period, as documented for other European areas (Alfani and Ryckbosch 2016; Alfani 2019, 2021), it would have been much more unequal around 1800. In the nineteenth and early twentieth centuries, Germany followed an exemplary "Kuznets curve" with rising inequality from 1850 to 1913 followed by a decline at least until the 1970s (Kuznets 1955; Dumke 1988, p. 13; Grant 2005, p. 304; Bartels 2019, p. 689). However, our results show that in this area, as elsewhere in Europe, inequality was rising well before that. This means that we need to consider other drivers of inequality than industrialization per se or economic growth more generally. Indeed Germany, which was on the losing side of the Little Divergence from the sixteenth century, is yet another example of a preindustrial European area where inequality growth could occur without economic growth. Similar to other recent studies (Scheidel 2017; Alfani and Di Tullio 2019; Pfister 2020; Alfani 2021), we consider as alternative explanations the role potentially played by demographic forces, as well as by processes of state formation and by changes in the levels of regressive taxation. While admittedly many questions remain open and will have to be targeted by future research, our study of preindustrial Germany offers new and relevant material to current debates on the roots of inequality in western societies, past and present.

\section{REFERENCES}

Abel, Wilhelm. Die Wüstungen des ausgehenden Mittelalters. Stuttgart: Gustav Fischer Verlag, 1976.

Acemoglu, Daron, Simon Johnson, and James A. Robinson. "Institutions as the Fundamental Cause of Long-Run Growth." In Handbook of Economic Growth, Volume 1A, edited by Philippe Aghion and Steven N. Durlauf, 385-472. Amsterdam: Elsevier, 2005.

Albers, Thilo N. H., Charlotte Bartels, and Moritz Schularick. "The Distribution of Wealth in Germany, 1895-2018." Unpublished Manuscript, 2020.

Alfani, Guido. "Wealth Inequalities and Population Dynamics in Northern Italy during the Early Modern Period." Journal of Interdisciplinary History 40, no. 4 (2010a): 513-49.

- "The Effects of Plague on the Distribution of Property: Ivrea, Northern Italy 1630.” Population Studies 64, no. 1 (2010b): 61-75. 
—. "Plague in Seventeenth Century Europe and the Decline of Italy: An Epidemiological Hypothesis.” European Review of Economic History 17, no. 4 (2013a): 408-30.

- Calamities and the Economy in Renaissance Italy. Houndmills: PalgraveMacmillan, 2013b.

—. "Economic Inequality in Northwestern Italy: A Long-Term View (Fourteenth to Eighteenth Centuries).” Journal of Economic History 75, no. 4 (2015): 1058-96.

_. "The Rich in Historical Perspective. Evidence for Preindustrial Europe (ca. 1300-1800)." Cliometrica 11, no. 3 (2017): 321-48.

_. "Wealth and Income Inequality in the Long Run of History." In Handbook of Cliometrics, edited by Claude Diebolt and Michael Haupert, 1-30. Berlin: Springer, 2019.

_. "The Economic History of Poverty, 1450-1800." In The Routledge History of Poverty in Europe, c. 1450-1800, edited by David Hitchcock and Julia McClure, 21-38. London: Routledge, 2020.

. "Preindustrial Inequality: Europe and Beyond." Journal of Economic Literature 59, no. 1 (2021): 3-44.

-. "Epidemics, Inequality and Poverty in Preindustrial and Early Industrial Times." Journal of Economic Literature, forthcoming, 2022.

Alfani, Guido, and Francesco Ammannati. "Long-Term Trends in Economic Inequality: The Case of the Florentine State, ca. 1300-1800." Economic History Review 70, no. 4 (2017): 1072-102.

Alfani, Guido, Francesco Ammannati, and Wouter Ryckbosch. "Poverty in Early Modern Europe: New Approaches to Old Problems.” Unpublished Manuscript, 2020.

Alfani, Guido, and Matteo di Tullio. The Lion's Share. Inequality and the Rise of the Fiscal State in Preindustrial Europe. Cambridge: Cambridge University Press, 2019.

Alfani, Guido, Victoria Gierok, and Felix Schaff. "Economic Inequality in Preindustrial Germany, ca. 1300-1850.” Ann Arbor, MI: Inter-university Consortium for Political and Social Research [distributor], 2021-07-01. https://doi.org/10.3886/ E144241V1.

Alfani, Guido, and Thomas E. Murphy. "Plague and Lethal Epidemics in the Pre-Industrial World." Journal of Economic History 77, no. 1 (2017): 314-43.

Alfani, Guido, and Wouter Ryckbosch. "Growing Apart in Early Modern Europe? A Comparison of Inequality Trends in Italy and the Low Countries, 1500-1800." Explorations in Economic History 62 (2016): 143-53.

Alfani, Guido, and Sergio Sardone. "Long-Term Trends in Economic Inequality in Southern Italy. The Kingdoms of Naples and Sicily, $16^{\text {th }}-18^{\text {th }}$ Centuries: First Results." Unpublished Manuscript. Economic History Association, 11-13 September Nashville Conference, 2015.

Ammann, Hektor. "Wie groß war die mittelalterliche Stadt?" In Die Stadt des Mittelalters. Erster Band, Begriffe, Entstehung und Ausbreitung, edited by Carl Haase, 415-22. Darmstadt: Wissenschaftliche Buchgesellschaft, 1978.

Angrist, Joshua, and Jörn-Steffen Pischke. Mostly Harmless Econometrics. Princeton: Princeton University Press, 2009.

Barbero, Alessandro. Storia del Piemonte: Dalla preistoria alla globalizzazione. Turin: Einaudi, 2008. 
Bartels, Charlotte. "Top Incomes in Germany, 1871-2014." Journal of Economic History 79, no. 3 (2019): 669-707.

Bátori, Ingrid, and Erdmann Weyrauch. Die bürgerliche Elite der Stadt Kitzingen: Studien zur Sozial- und Wirtschaftsgeschichte einer landesherrlichen Stadt im 16. Jahrhundert. Stuttgart: Klett-Cotta, 1982.

Bengtsson, Erik, Anna Missiaia, Mats Olsson, and Patrick Svensson. "Wealth Inequality in Sweden, 1750-1900." Economic History Review 71, no. 3 (2018): 772-79.

Bracht, Johannes, and Ulrich Pfister. Landpacht, Marktgesellschaft und agrarische Entwicklung: Fünf Adelsgüter zwischen Rhein und Weser, 16. Bis 19. Jahrhundert. Stuttgart: Franz Steiner Verlag, 2020.

Braudel, Fernand. Il secondo Rinascimento. Turin: Einaudi, 1986.

Broadberry, Stephen, Bruce M. S. Campbell, Bas van Leeuwen, Alexander Klein, and Mark Overton. British Economic Growth, 1270-1870. Cambridge: Cambridge University Press, 2015.

Bücher, Karl. Die Entstehung der Volkswirtschaft: Vorträge und Schriften. Tübingen: Verlag der H. Laupp'schen Buchhandlung, 1917.

Burnard, Trevor, Laura Panza, and Jeffrey Williamson. "Living Costs, Real Incomes and Inequality in Colonial Jamaica." Explorations in Economic History 71 (2019): 55-71.

Canbakal, Hülya, Alpay Filiztekin, and Irfan Kokdas. "Inequality and the Rich in Ottoman Anatolia and the Balkans 1660-1840.” Unpublished Manuscript. World Economic History Congress, 30 July-3 August, Boston, 2018.

Clark, Gregory. "The Condition of the Working Class in England, 1209-2004.” Journal of Political Economy 113, no. 6 (2005): 1307-40.

Clodfelter, Micheal. Warfare and Armed Conflicts. A Statistical Encyclopedia of Casualty and Other Figures, 1492-2015, fourth ed. Jefferson: McFarland, 2017.

Dollinger, Philippe. The German Hansa (The Emergence of International Business 1200-1800, Vol. 1). London: Routledge, 1999.

Dorner, Friedrich. Die Steuern Nördlingens zu Ausgang des Mittelalters. Nördlingen: Kommissionsverlag der C.B. Beck’schen Buchhandlung, 1905.

Dumke, Rolf H. "Income Inequality and Industrialization in Germany 1850-1913." Research in Economic History 11 (1988): 1-47.

Eckert, Edward A. The Structure of Plagues and Pestilences in Early Modern Europe. Central Europe, 1560-1640. Basel: Karger, 1996.

Findlay, Ronald, and Kevin O'Rourke. Power and Plenty: Trade, War, and the World Economy in the Second Millennium. Princeton: Princeton University Press, 2007.

Franz, Günther. Der Dreißigjährige Krieg und das deutsche Volk. Stuttgart: Gustav Fischer, 1961.

Fügedi, Erik. "Steuerlisten, Vermögen und soziale Gruppen in mittelalterlichen Städten." In Städtische Gesellschaft und Reformation (Spätmittelalter und Frühe Neuzeit. Tübinger Beiträge zur Geschichtsforschung 12), edited by Ingrid Bátori, 58-96. Stuttgart: Klett-Cotta, 1980.

García-Montero, Héctor. "Long-Term Trends in Wealth Inequality in Catalonia, 1400 1800: Initial Results." Carlo F. Dondena Centre for Research on Social Dynamics Working Paper No. 79, Bocconi University, Italy, 2015.

Gömmel, Rainer. Die Entwicklung der Wirtschaft im Zeitalter des Merkantilismus 1620-1800. Enzyklopädie Deutscher Geschichte Band 46. München: Oldenbourg Verlag, 1998. 
Grant, Oliver. Migration and Inequality in Germany 1870-1913. Oxford: Oxford University Press, 2005.

Hartung, Johannes. "Die direkten Steuern und die Vermögensentwicklung in Augsburg von der Mitte des 16. bis zum 18. Jahrhundert." Jahrbuch für Gesetzgebung, Verwaltung und Volkswirtschaft im Deutschen Reich 22, no. 1 (1898): 167209.

Hartwig, J. Der Lübecker Schoss bis zur Reformationszeit. Leipzig: Duncker \& Humblot, 1903.

Isenmann, Eberhard. "The Holy Roman Empire in the Middle Ages." In The Rise of the Fiscal State in Europe c.1200-1815, edited by Richard Bonney, 245-80. Oxford: Oxford University Press, 1999.

- Die Deutsche Stadt im Mittelalter 1150-1550. Stadtgestalt, Recht, Verfassung, Stadtregiment, Kirche, Gesellschaft, Wirtschaft. Wien Köln Wismar: Böhlau Verlag, 2014.

Jecht, Horst. "Studien zur gesellschaftlichen Struktur der mittelalterlichen Städte." Vierteljahreszeitschrift für Sozial- und Wirtschaftsgeschichte 19, no. 1 (1926): 48-85.

Jenks, Stuart. "Von den Archaischen Grundlagen bis zur Schwelle der Moderne (ca. 1000-1450)." In Deutsche Wirtschaftsgeschichte - Ein Jahrtausend im Überblick, edited by Michael North, 15-111. München: C.H. Beck, 2005.

Jütte, Robert. Obrigkeitliche Armenfürsorge in Deutschen Reichsstädten der Frühen Neuzeit: Städtisches Armenwesen in Frankfurt am Main und Köln. Köln: Böhlau, 1984.

—. Poverty and Deviance in Early Modern Europe. Cambridge: Cambridge University Press, 1994.

Kirchgässner, Bernhard. Das Steuerwesen der Reichsstadt Konstanz 1418-1460. Konstanz: Kommissions-Verlag Jan Thorbecke, 1960.

- Wirtschaft und Bevölkerung der Reichsstadt Eßlingen im Spätmittelalter. Nach den Steuerbüchern 1360-1460. Esslingen: Verlag des Stadtarchivs Eßlingen, 1964.

—_. "Probleme quantitativer Erfassung städtischer Unterschichten im Spätmittelalter, besonders in den Reichsstädten Konstanz und Esslingen." In Gesellschaftliche Unterschichten in den südwestdeutschen Städten. Protokoll über die V. Arbeitstagung des Arbeitskreises für südwestdeutsche Stadtgeschichtsforschung, edited by Erich Maschke and Jürgen Sydow, 75-89. Stuttgart: W. Kohlhammer Verlag, 1967.

Kocka, Jürgen. Weder Stand noch Klasse: Unterschichten um 1800. Bonn: Verlag J.H.W. Dietz Nachf., 1990.

Kuznets, Simon. "Economic Growth and Income Inequality." American Economic Review 45, no. 1 (1955): 1-28.

Lindert, Peter H. "Toward a Comparative History of Income and Wealth Inequality." In Income Distribution in Historical Perspective, edited by Yehojachin S. Brenner, Hartmut Kaelble, and Mark Thomas, 212-31. Cambridge: Cambridge University Press, 1991.

Lindert, Peter H., and Jeffrey G. Williamson. Unequal Gains. American Growth and Inequality since 1700. Princeton: Princeton University Press, 2016.

Malinowski, Mikolaj, and Jan Luiten Van Zanden. "Income and Its Distribution in Preindustrial Poland." Cliometrica 11, no. 3 (2017): 375-404. 
Maschke, Erich. "Die Schichtung der mittelalterlichen Stadtbevölkerung Deutschlands als Problem der Forschung." In Mélanges en honneur de Fernand Braudel, Bd. 2: Histoire économique du monde méditerranéen (1450-1650). Méthodologie de l'histoire et des sciences humaines, 367-79. Toulouse: Privat, 1973.

Milanovic, Branko. Worlds Apart. Measuring International and Global Inequality. Princeton: Princeton University Press, 2005.

- Global Inequality: A New Approach for the Age of Globalization. Cambridge, MA: Harvard University Press, 2016.

Moraw, Peter. Von offener Verfassung zu gestalteter Verdichtung: Das Reich im späten Mittelalter 1250 bis 1490. Frankfurt a.M.: Verlag Ullstein, 1989.

Nicolini, Esteban A., and Fernando Ramos Palencia. "Decomposing Income Inequality in a Backward Pre-Industrial Economy: Old Castile (Spain) in the Middle of the 18th Century." Economic History Review 69, no. 3 (2016): 747-72.

_. "Comparing Income and Wealth Inequality in Pre-Industrial Economies: The Case of Castile (Spain) in the Eighteenth Century." European Review of Economic History 25, no. 4 (2021): 680-702.

Ogilvie, Sheilagh. "Germany and the Seventeenth-Century Crisis." The Historical Journal 35 (1992): 417-41.

—. "Proto-Industrialization in Germany." In European Proto-Industrialization, edited by Sheilagh Ogilvie and Markus Cerman, 118-36. Cambridge: Cambridge University Press, 1996a.

- "The Beginnings of Industrialization." In Germany - A New Social and Economic History 1630-1800, edited by Sheilagh Ogilvie, 261-308. London: Arnold, 1996b.

__. "Serfdom and the Institutional System in Early Modern Germany." In Serfdom and Slavery in the European Economy $11^{\text {th }}-18^{\text {th }}$ Centuries, edited by Simonetta Cavaciocchi, 33-56. Florence: Firenze University Press, 2014.

—. "Thinking Carefully about Inclusiveness: Evidence from European Guilds." Journal of Institutional Economics 17, no. 2 (2021): 185-200.

Ohler, Norbert. "Zu den Vermögenssteeuern der Stadt Freiburg i. Br. in Spätmittelalter und früher Neuzeit." Zeitschrift des Breisgau Geschichtsvereins 97 (1978): 5-28.

Outram, Quentin. "The Socio-Economic Relations of Warfare and the Military Mortality Crises of the Thirty Years' War." Medical History 45 (2001): 151-84.

Pfister, Ulrich. "Economic Growth in Germany, 1500-1850." Contribution to the Quantifying Long Run Economic Development Conference, University of Warwick in Venice, 22-24 March 2011.

- "The Inequality of Pay in Pre-Modern Germany, Late $15^{\text {th }}$ Century to 1889." Jahrbuch für Wirtschaftsgeschichte 60, no. 1 (2019): 209-43.

_. "Economic Inequality in Germany, c. 1500-1800." In Economic Inequality in Pre-Industrial Societies: Causes and Effect, edited by Gampiero Nigro, 301-24. Florence: Firenze University Press, 2020.

Piketty, Thomas. Capital in the Twenty-First Century. London: Belknap Press, 2014. . "Putting Distribution Back at the Center of Economics: Reflections on Capital in the Twenty-First Century." Journal of Economic Perspectives 29, no. 1 (2015): 67-88.

Ray, Debraj. Development Economics. Princeton: Princeton University Press, 1998.

Redlich, Fritz. "Contributions in the Thirty Years' War." Economic History Review 12, no. 2 (1959): 247-54. 
Reis, Jamie. "Deviant Behaviour? Inequality in Portugal 1565-1770." Cliometrica 11, no. 2 (2017): 297-319.

Robisheaux, Thomas. Rural Society and the Search for Order in Early Modern Germany. Cambridge: Cambridge University Press, 1989.

Röck, Bernd. Eine Stadt in Krieg und Frieden - Studien zur Geschichte der Reichsstadt Augsburg zwischen Kalenderstreit und Parität, Zweiter Teilband. Göttingen: Vandenhoeck \& Ruprecht, 1989.

Rodepeter, Ralf. “Die Pest - ein Fall für Ökonomen?” In Volkswirtschaft in Fünfzehn Fällen: Studien in Angewandter Mikro- Und Makroökonomie, edited by Axel Börsch-Supan and Reinhold Schnabel, 3-16. Wiesbaden: Gabler, 1998.

Rösener, Werner. "The Agrarian Economy, 1300-1600." In Germany: A New Social and Economic History 1450-1630, edited by Bob Scribner, 63-83. London: Arnold, 1996.

Ryckbosch, Wouter. "Economic Inequality and Growth before the Industrial Revolution: The Case of the Low Countries (Fourteenth to Nineteenth Centuries)." European Review of Economic History 20 (2016): 1-22.

Sabean, David. Property, Production, and Family in Neckarhausen, 1700-1870. Cambridge: Cambridge University Press, 1990.

Saito, Osamu. "Growth and Inequality in the Great and Little Divergence Debate: A Japanese Perspective." Economic History Review 68, no. 2 (2015): 399-419.

Santiago-Caballero, Carlos. C. "Income Inequality in Central Spain, 1690-1800." Explorations in Economic History 48, no. 1 (2011): 83-96.

Schaff, Felix S. F. "When 'The State Made War', What Happened to Economic Inequality? Evidence from Preindustrial Germany (c.1400-1800)." LSE Economic History Working Paper No. 311, London, UK, 2020.

Scheidel, Walter. The Great Leveller: Violence and the History of Inequality from the Stone Age to the Twenty-First Century. Princeton: Princeton University Press, 2017.

Schilling, Heinz. Aufbruch und Kriese: Deutschland 1517-1648. München: Siedler, 1994.

Schmoller, Gustav. "Die Einkommensverteilung in alter und neuer Zeit.” Jahrbuch für Gesetzgebung, Verwaltung und Volkswirtschaft 19 (1895): 1067-94.

Schrader, Friedrich. "Die Stadt Erfurt in ihren wirtschaftlichen und sozialen Verhältnissen nach Beendigung des 30jährigen Krieges." Mitteilungen des Vereins für die Geschichte und Altertumskunde von Erfurt 40/41 (1921): 142-62.

Scott, Tom. Society and Economy in Germany, 1300-1600. Houndmills: PalgraveMacmillan, 2002.

Sreenivasan, Govind P. The Peasants of Ottobeuren, 1487-1726: A Rural Society in Early Modern Europe. Cambridge: Cambridge University Press, 2004.

Steckel, Richard H., and Carolyn M. Moehling. "Rising Inequality: Trends in the Distribution of Wealth in Industrializing New England." Journal of Economic History 61, no. 1 (2001): 160-83.

Stoob, Heinz (ed.). "Stadtformen und städtisches Leben im späten Mittelalter.” In Die Stadt, 151-90. Köln: Böhlau Verlag, 1985.

Tilly, Charles. Coercion, Capital, and European States, 990-1992. Cambridge: Blackwell, 1992.

Uthmann, Karl J. Sozialstruktur und Vermögensbildung im Hildesheim des 15. und 16. Jahrhunderts. Bremen, Horn: Walter Dorn Verlag, 1957. 
Van Zanden, Jan Luiten. "Tracing the Beginning of the Kuznets Curve: Western Europe during the Early Modern Period." Economic History Review 48, no. 4 (1995): 643-64.

Volckart, Oliver. Wettbewerb und Wettbewerbsbeschränkung im vormodernen Deutschland 1000-1800. Tübingen: Mohr Siebeck, 2002.

—. "The Dear Old Holy Roman Realm, How Does it Hold Together?" Monetary Policies, Cross-Cutting Cleavages and Political Cohesion in the Age of Reformation." German History 38, no. 3 (2020): 365-86.

Von Hippel, Wolfgang. Türkensteuer und Bürgerzählung. Stuttgart: W. Kohlhammer Verlag, 2009.

Wade, Robert H. "The Strange Neglect of Income Inequality in Economics and Public Policy." In Toward Human Development: New Approaches to Macroeconomics and Inequality, edited by Andrea Cornia Giovanni and Frances Steward, 99-121. Oxford: Oxford University Press, 2014.

Warde, Paul. Ecology, Economy and State Formation in Early Modern Germany. Cambridge: Cambridge University Press, 2006.

Wegge, Simone. "Inheritance Institutions and Landholding Inequality in NineteenthCentury Germany: Village-Level Evidence from Hesse-Cassel." Journal of Economic History 80, no. 3 (2021): 909-42.

Whaley, Joachim. Germany and the Holy Roman Empire Volume 1: From Maximilian I to the Peace of Westphalia 1493-1648. Oxford: Oxford University Press, 2013a.

- Germany and the Holy Roman Empire Volume 2: From the Peace of Westphalia to the Dissolution of the Reich 1648-1806. Oxford: Oxford University Press, 2013b.

Wilson, Peter H. The Thirty Years' War: Europe's Tragedy. Cambridge: Cambridge University Press, 2009.

- The Holy Roman Empire: A Thousand Years of Europe's History. London: Penguin, 2017.

Wozniak, Thomas. Quedlinburg im 14. Und 16. Jahrhundert-Ein sozialtopographischer Vergleich. Berlin: Akademie Verlag, 2013. 